Article

\title{
Residue and Agronomic Management to Reduce the Continuous Corn Yield Penalty
}

\author{
Alison M. Vogel and Frederick E. Below * \\ Department of Crop Sciences, University of Illinois, Urbana, IL 61801, USA; amvoge190@gmail.com \\ * Correspondence: fbelow@illinois.edu; Tel.: +1-217-333-9745
}

Received: 16 August 2019; Accepted: 18 September 2019; Published: 20 September 2019

check for updates

\begin{abstract}
Accelerated residue degradation and nutrient cycling will be necessary to maximize yield potential in corn (Zea mays L.) grown continuously and in other high-volume residue situations. This study aimed to test if residue management and agronomic inputs could lessen the continuous corn yield penalty (CCYP) compared to a corn following soybean [Glycine max (L.) Merr.] rotation. Field experiments conducted during 2017 and 2018 at Champaign, IL, USA compared plots of 15th year continuous corn to long-term corn-soybean rotation plots. The previous year's corn crop residue was either downsized (chopped) or harvested with standard knife rollers, with further chemical management of either a biocatalyst or ammonium sulfate, or it was left untreated. A standard management system of 79,000 plants ha ${ }^{-1}$ and a base rate of nitrogen fertilizer was compared to an intensive management system of 111,000 plants ha ${ }^{-1}$ with additional fertilizer and a foliar fungicide. Although continuous corn cropping stress was not detected until R2 (kernel blister stage), the CCYP was $1.30 \mathrm{Mg} \mathrm{ha}^{-1}$. Sizing residue enhanced overwinter residue decomposition and increased yield by $0.31 \mathrm{Mg} \mathrm{ha}^{-1}$ regardless of rotation and by $0.53 \mathrm{Mg} \mathrm{ha}^{-1}$ in continuous corn. Intensive inputs in combination with residue sizing increased grain yield of continuous corn by $1.15 \mathrm{Mg} \mathrm{ha}^{-1}$ over standard-management rotated yields. Therefore, combining mechanical and agronomic managements can reduce corn residue and the CCYP for more sustainable crop production.
\end{abstract}

Keywords: Calmer's BT Chopper; continuous corn yield penalty (CCYP); corn-soybean rotation; Extract PBA; hybrid; intensive management; maize; residue management; sizing

\section{Introduction}

In high volume corn (Zea mays L.) residue producing situations, such as increased planting density [1,2], reduced tillage [3], corn following corn systems [4,5], and increased grain yields [6], the need could arise for accelerated residue degradation and nutrient cycling to maximize subsequent crop yield potential. Although it is widely accepted that grain yields of continuously grown corn are generally less than when corn is rotated with soybean [Glycine max (L.) Merr.], denoted as the continuous corn yield penalty (CCYP), continuous corn remains a viable cropping system for many Midwestern USA producers. Grain yield reductions from continuous corn compared to first-year corn in a corn-soybean rotation typically range from 10 to $15 \%$ [2,4,5,7-14]. Residue accumulation, soil nitrogen availability or immobilization, and the weather have been documented as the primary agents of the CCYP [5]. Additionally, the penalty is not moderated by successive years of continuous corn production and may intensify due to the accumulation of residue [4,5]. Potential options to increase corn yields and reduce the causative factors of the CCYP are mechanical and chemical residue management, enhanced fertility, and more intensive agronomic systems.

With increasing yield levels, planting densities, and reduced- or no-tillage practices, the quantity of plant residue remaining after harvest is increasing, and residue management is becoming more important for production sustainability. Additional corn residue remaining in the spring can cause 
delayed and more variable emergence of the subsequent crop due to slower soil warming $[15,16]$ and can impede seedling emergence [17], resulting in uneven emergence and reduced final grain yield potential $[18,19]$. Residue removal is one option for residue management, although removal could deplete the soil of the natural recycling of residue into essential nutrients and utilization by the following crop [20].

Previous crop residue type and quantity remaining on the soil surface impacts soil water evaporation, soil temperature, nutrient cycling, and soil organic matter formation, all of which have a role in soil quality and crop productivity [21,22]. Residue C:N (carbon to nitrogen) ratio plays a large role in the initial rates of residue degradation, with ratios below 20 to 30 promoting decomposition and nutrient release [23-25]. Corn residue has a C:N ratio of approximately 31 for leaves and 78 for stalk material, bolstering nitrogen immobilization [25-27]. Net soil nitrogen mineralization is reduced in continuous corn production compared to corn following soybean because of differences in the quality (C:N ratio) and the quantity of the previous crops' residue $[28,29]$. As a result, to enhance seedling emergence uniformity and early season plant vigor, synchronizing the timing when crop residue nutrients become readily available rather than when they are immobilized to early growth could offset the negative effects of high-volume residue environments. One management practice that may increase the residue decomposition rate is the use of specialty combine heads at harvest that mechanically chop the corn residue to a smaller average fragment size, known as "sizing". Shattering stalks, sizing them, and evenly distributing this residue helps promote the biological processes of decomposition during mild fall and early spring temperatures when residue decay is active $[24,30]$. Microorganisms can quickly colonize the easily digestible and exposed inner pith of the stalk material when sized, presumably enhancing residue decomposition. As fungi, bacteria, and actinomycetes proliferate, they further digest the more resistant cellulose and then the toughest lignin of the outer stalk rind [24,31].

Although several companies in the agricultural sector promote products that contain microorganisms or biocatalysts to enhance residue degradation and nutrient cycling, scientific field studies and publications documenting their effectiveness are limited. These products are designated as biostimulants or biorationals and are utilized to stimulate and/or enhance natural processes to improve nutrient availability to the plant or allow plants to better tolerate stresses [32,33]. Microorganisms, humic acids, amino acids, or seaweed extracts are some examples of the diversity of products in this category, which can be applied to the soil, the seed, or the plant. These products can be isolated or derived from manure, plant residues, or soil. A microbial-based biostimulant derived from a bioreactor system (biologically active environment with a continuously maintained microbial community) is Extract powered by Accomplish (Extract PBA; Loveland Products, Loveland, CO, USA). It is designed to help growers manage crop residue by promoting microbial activity and nutrient release from crop residue. The final product contains bacteria and bacterial metabolites combined with ammonium thiosulfate. The bacteria in the final product primarily consist of Acidovorax facilis, Bacillus licheniformis, Bacillus marinus, Bacillus megaterium, Bacillus oleronius, Bacillus subtilis, and Rhodococcus rhodochrous [33]. The bacterial metabolites consist of organic acids, peptides, and enzymes that have been documented to enhance the solubility of phosphorus [34,35], potassium [36-38], and other macro- and micro-nutrients [32]. In addition, microbial activity appears to be further enhanced when microbial-based treatments are combined with urea ammonium nitrate (UAN, similar to Extract PBA) [39]. Fall nitrogen applications to promote decomposition by narrowing the C:N ratio of the surface residue have been examined previously with varied results $[40,41]$.

Agronomic management intensification (i.e., high input), including additional seeding rate, broadcast and banded fertilizer, and a foliar fungicide, plays a critical role in offsetting the negative causative effects of continuously grown corn [42] and promotes greater yields [43]. Compared to standard management practices, intensive management has been found to extend the growing season of the crop, including the grain-filling period [43]. Improved agronomic management combined with ideal weather conditions may help alleviate the typically-stressed growing environments of continuous corn and increase yield. 
Additionally, hybrid selection has been shown to significantly influence the magnitude of the CCYP $[2,4]$. Hybrids that can tolerate continuous corn situations may be more competitive for resources; therefore, the proper hybrid selection in combination with intensive management practices will contribute to a multifaceted approach to alleviate the continuous corn yield penalty. The objective of this research was to identify residue and agronomic management practices that lessen yield losses due to high crop-residue environments (e.g., high yielding corn rotated with soybean or high residue systems of continuous corn). The principal factors of residue management (i.e., mechanical and chemical applications), input level (i.e., adding fertility and leaf protection), and hybrid selection were evaluated to determine their roles in increasing yield and as methods of reducing the continuous corn yield penalty.

\section{Materials and Methods}

\subsection{Agronomic Practices}

Field experiments at Champaign, Illinois, USA in 2017 and 2018 assessed the yield penalty associated with using adjacent plots grown to continuous corn for the 15th year versus a long-term corn following soybean rotation field grown with contrasting mechanical and chemical residue treatments in either a standard or an intensive management system and with two commercially-available hybrids (Table 1). The trial was planted 25 April 2017 and 8 May 2018 using two neighboring long-term sites dedicated to crop rotation research and consisting of a Flanagan-Drummer-Catlin soil association. The sites were tile drained and unirrigated. The preplanting soil properties at the $0-30 \mathrm{~cm}$ depth for 2017 and 2018 included, respectively, 39 and $38 \mathrm{~g} \mathrm{~kg}^{-1}$ organic matter, $\mathrm{pH} 6.1$ and 6.3, 26 and $24 \mathrm{mg} \mathrm{kg}^{-1} \mathrm{P}$, and 141 and $95 \mathrm{mg} \mathrm{kg}^{-1} \mathrm{~K}$. The minerals $\mathrm{P}$ and $\mathrm{K}$ were extracted using Mehlich III solution. Plots were $11.4 \mathrm{~m}$ in length with $76 \mathrm{~cm}$ row spacing and four rows in width.

Table 1. Treatments used in the evaluation of corn residue management, input intensity, and germplasm influences on the continuous corn yield penalty (CCYP) at Champaign, IL during 2017 and 2018. Two rotations each received two mechanical and three chemical residue management treatments in combination with two input levels described in the Materials and Methods section and two hybrids.

\begin{tabular}{|c|c|c|c|c|}
\hline \multirow[b]{2}{*}{ Rotation } & \multicolumn{2}{|c|}{ Residue Management } & \multirow[b]{2}{*}{ Input Level } & \multirow[b]{2}{*}{ Hybrid } \\
\hline & Mechanical & Chemical & & \\
\hline Continuous Corn & Standard stalk rollers & Untreated & Standard & 6110SS \\
\hline Corn-Soybean & Calmer's BT Choppers & $\begin{array}{c}\text { Extract PBA } \\
\text { Ammonium Sulfate }\end{array}$ & Intensive & 6594SS \\
\hline
\end{tabular}

PBA: powered by Accomplish.

For the mechanical residue treatments (i.e., harvest method), the previous year's corn crop was harvested 4 October 2016 and 21 September 2017 with a combine head equipped with Calmer BT Chopper stalk rollers (sizing residue to 3-4 cm maximum fragments; Calmer Corn Heads, Inc., Alpha, IL, USA) or with standard knife rollers (not sized). Both mechanical residue treatments were managed chemically in the fall with Extract PBA (6-0-0-13S, Loveland Products, Loveland, CO, USA) or with ammonium sulfate (AMS; 21-0-0-24S) applied 11 November 2016 and 20 October 2017 over the crop residue and compared to an untreated control. According to the label, Extract PBA was sprayed at $18.7 \mathrm{~L} \mathrm{ha}^{-1}$ mixed with $9.4 \mathrm{~L} \mathrm{ha}^{-1}$ UAN (28-0-0) using a total spray solution rate of $140 \mathrm{~L} \mathrm{ha}^{-1}$ (providing $4.7 \mathrm{~kg} \mathrm{~N} \mathrm{ha}^{-1}$ total). Granular AMS was broadcast applied at $224 \mathrm{~kg} \mathrm{ha}^{-1}$ to provide $47 \mathrm{~kg} \mathrm{~N} \mathrm{ha}^{-1}$. Where soybean was the previous crop, i.e., first year corn in the corn-soybean rotation, mechanical treatments could not be implemented on the soybean residue, but this residue also received both chemical treatments in October, and the corn residue had been sized the previous fall.

Across rotation and mechanical residue treatments, the standard management system (i.e., standard input) was seeded to achieve a final stand of 79,000 plants $\mathrm{ha}^{-1}$ and received a base rate 
of nitrogen fertilizer (202 $\mathrm{kg} \mathrm{N} \mathrm{ha}^{-1}$ as UAN) preplant with no additional fertility and no fungicide application. The intensive management system was seeded to achieve a final stand of 111,000 plants ha ${ }^{-1}$ and consisted of broadcast potassium and boron $\left(84 \mathrm{~kg} \mathrm{~K}_{2} \mathrm{O}\right.$ and $0.6 \mathrm{~kg} \mathrm{~B} \mathrm{ha}^{-1}$ as Aspire; 0-0-58-0.5B; The Mosaic Co., Plymouth, MN, USA) and phosphorus, nitrogen, sulfur, and zinc ( $112 \mathrm{~kg} \mathrm{P}_{2} \mathrm{O}_{5}, 34 \mathrm{~kg} \mathrm{~N}$, $28 \mathrm{~kg} \mathrm{~S}$, and $2.8 \mathrm{~kg} \mathrm{Zn} \mathrm{ha}^{-1}$ as MicroEssentials SZ; 12-40-0-10S-1Zn; The Mosaic Co., Plymouth, MN, USA) banded 8-10 cm directly beneath the crop row preplant using an applicator toolbar (6000 series universal fertilizer applicator; Dawn Equipment, Sycamore, IL, USA), additional sidedressed (V5 growth stage; 5 fully formed leaves; 8 June 2017 and 1 June 2018) nitrogen fertilizer [ $67 \mathrm{~kg} \mathrm{~N} \mathrm{ha}^{-1}$ as stabilized Limus urea; $\mathrm{CO}\left(\mathrm{NH}_{2}\right)_{2}+\mathrm{n}$-(n-butyl) thiophosphoric triamide $+\mathrm{n}$-(n-propyl) thiophosphoric triamide; 46-0-0; $269 \mathrm{~kg} \mathrm{~N} \mathrm{ha}^{-1}$ total; BASF, Florham Park, NJ, USA], and a foliar fungicide application of Headline AMP (BASF, Florham Park, NJ, USA), a product containing pyraclostrobin (carbamic acid, [2-[[[1-(4-chlorophenyl)-1H-pyrazol-3-yl]oxy]methyl]phenyl]methoxy-, methyl ester) and metconazole(5-[(4-chlorophenyl)methyl]-2,2-dimethyl-1-(1H-1,2,4-triazol-1-ylmethyl)cyclopentanol) at the labeled rates of 0.15 and $0.06 \mathrm{~kg}$ a. i. ha ${ }^{-1}$, respectively. Strobilurin fungicides control foliar fungal diseases as well as increase grain yield, even when fungal diseases are not present [44]. The fungicide was applied at plant growth stage VT/R1 (tassel/silk emergence; 14 July 2017 and 5 July 2018) using a $\mathrm{CO}_{2}$-pressurized backpack sprayer via an aqueous suspension at $140 \mathrm{~L} \mathrm{H}_{2} \mathrm{O} \mathrm{ha}^{-1}$ and mixed with a nonionic surfactant (MasterLock; WinField Solutions, LLC, St. Paul, MN, USA) at $0.45 \mathrm{~kg} \mathrm{ha}^{-1}$.

To assess the hybrid variation in response to rotation (i.e., CCYP), hybrids were selected to provide contrasting yield responses when grown in a continuous corn situation (Table 1). The hybrids grown included 6110SS (110 Relative Maturity [RM]) and 6594SS (113 RM) (WinField United, LLC., Arden Hills, MN, USA). The selection was based on previously determined ratings by WinField United with values ranging from 1-3 indicating that the hybrid is suitable for a continuous corn production system (potentially less CCYP), while ratings of 7-9 indicate that extra management is necessary to overcome the CCYP (potentially greater CCYP). The hybrids used had moderate $(6110 S S=5)$ or high $(6594 S S=7)$ ratings for growth response to continuous corn. Additionally, they were selected as hybrids that would remain accessible for the duration of the study.

\subsection{Residue Samplings, Emergence Assessment, Plant Biomass Samplings, Health Assessment, and Harvest}

To determine percent dry weight reduction over the winter from mechanical and chemical residue management treatments, corn residue (leaves and stalks) was collected in all relevant treatments. Two samples per plot (from an area of $0.25 \mathrm{~m}^{2}$ each) were collected post-harvest and post-chemical application (20 October 2016 and 19 October 2017), placed in nylon mesh bags and weighed, with one sample placed back in-field on the soil surface to overwinter and the other dried to $0 \%$ moisture in a forced air oven at $75^{\circ} \mathrm{C}$ for a week to estimate initial dry weight. Immediately prior to planting (25 April 2017 and 19 April 2018), the in-field samples were collected and dried at $75^{\circ} \mathrm{C}$ for a week to determine overwinter residue degradation percentage. Overwintered samples were not dried until after collection, since the drying process with heat as low as $50^{\circ} \mathrm{C}$ to $60^{\circ} \mathrm{C}$ can produce additional lignin through nonenzymatic browning [45,46], altering microbial decay.

Seedling emergence data were obtained daily from a $305 \mathrm{~cm}$ row section of the second yield row and compared to the known planting density. Corn plant sampling for biomass accumulation was conducted on 12 June 2017 and 6 June 2018 (V6; six fully formed leaves; both shoots and roots) and 14 September 2017 and 5 September 2018 (R6; physiological maturity; aboveground-plant only). Sampling consisted of manually excising six plants from the outer two rows at V6 and from the center two rows of each plot at R6 to determine biomass. Root systems were excavated using a shovel to dig $25-30 \mathrm{~cm}$ diameter around the base of the shoot and $25-30 \mathrm{~cm}$ deep. Soil was removed using pressurized water until the roots were soil free. Plants at the V6 growth stage were dried to $0 \%$ moisture, divided into shoot and root fractions, and weighed. The plants at R6 were partitioned into grain and stover (including husk) components, and biomass was determined by weighing the total fresh stover and then processing it through a brush chipper (BC600XL; Vermeer Corporation, Pella, IA, USA) to obtain 
representative stover subsamples. The stover subsamples were immediately weighed to determine aliquot fresh weight and then weighed again after drying to $0 \%$ moisture in a forced air oven at $75^{\circ} \mathrm{C}$ to determine subsample aliquot dry weight and calculate dry biomass. Corn ears were dried and then weighed to obtain grain plus cob weight. The grain was removed using a corn sheller (AEC Group, St Charles, IA, USA) and analyzed for moisture content (Dickey John GAC 2500-AGRI; GSF, Ankeny, IA, USA). Cob weight was obtained by difference, and dry stover and cob weights were summed to calculate the overall R6 stover biomass.

To assess treatment effects on plant health, canopy greenness (normalized difference vegetation index, NDVI) was measured at the V8 growth stage (eight fully formed leaves; 23 June 2017 and 14 June 2018) with a Crop Circle ACS-201 sensor (Holland Scientific, Lincoln, NE, USA) positioned approximately $50 \mathrm{~cm}$ over the plant canopy (at 10 readings per second) and walking at a constant speed in each plot. Additionally, leaf greenness was measured at the R2 growth stage (3 August 2017 and 26 July 2018) with a Minolta SPAD-502 chlorophyll meter (Specialty Products Agricultural Division model 502; Spectrum Technologies, East-Plainfield, IL, USA) on the lamina at the midleaf region of 10 ear leaves (with no lesions) per plot. Prior to harvest, final stand count was tallied from the center two yield rows of each plot to confirm plant populations.

The entire center two rows of each plot were mechanically harvested for determination of grain yield at physiological maturity, and values are presented at $0 \%$ moisture. Subsamples of harvested grain were evaluated for grain quality (i.e., protein, oil, and starch concentrations) using near-infrared transmittance spectroscopy (NIT) (Infratec 1241 Grain Analyzer, FOSS, Hillerod, Denmark) with values presented at $0 \%$ moisture. Yield components (i.e., average weight per seed and seed number) were also quantified for each plot with values presented at $0 \%$ moisture.

\subsection{Statistical Analysis}

Treatments were arranged as a split-split plot in a randomized complete block design with crop rotation as the whole plot factor. Mechanical residue management was the sub-plot factor, with chemical residue management, input level, and hybrid randomized in a complete factorial at the sub-sub plot level. Four replications were evaluated for a total of 192 plots each year. The CCYP was calculated as the difference in yield when a hybrid was grown in the corn-soybean rotation minus the yield when grown in continuous corn, and it was averaged across all other treatments unless otherwise specified. All data are presented as the average of the two years, 2017 and 2018.

Parameters were analyzed using the PROC MIXED procedure (SAS 9.4, SAS Institute, Cary, NC, USA). Rotation, mechanical residue management, chemical residue management, input level, and hybrid were included as fixed effects, and year and replication were included as random effects. Least square means were separated using the PDIFF option of LSMEANS in SAS PROC MIXED. Due to the fastidious nature of biostimulants and the limited field-based research conducted with them, significance was declared at $p \leq 0.10$ to be more certain that we did not miss detecting a difference that may exist. Pearson's correlation coefficient was used to evaluate the linear association between grain yield and measured parameters across all treatments using the CORR procedure of SAS.

Residue decomposition evaluations were arranged at the setup sites in a split-split plot design with crop rotation (first year corn in a corn-soybean rotation and 15th year continuous corn) as the main plot, mechanical residue management as the sub-plot, and chemical residue management randomized within each sub-sub plot. Four replications were evaluated for a total of 48 plots per year. 


\section{Results and Discussion}

\subsection{Temperature and Precipitation}

The 2017 crop growing season experienced excessive rainfall from late April through early May during crop emergence, while the 2018 crop growing season experienced excessive rainfall in June (Table 2). During the remainder of the 2017 growing season (June through September), rainfall was limited, while in 2018, rainfall was similar to the 30-year average. Temperature for each month of the growing season in 2017 was similar to the long-term average. In 2018, corn development rapidly progressed in May due to warmer than average temperatures.

Table 2. Precipitation and temperature during the production season at Champaign, IL in 2017 and 2018 compared to the 30-year average. Values were obtained from the U.S. National Oceanic and Atmospheric Administration, and values in parentheses are the deviations from the 30-year average.

\begin{tabular}{ccccc}
\hline & \multicolumn{2}{c}{ Precipitation } & \multicolumn{2}{c}{ Temperature } \\
\cline { 2 - 5 } Month & $\mathbf{2 0 1 7}$ & $\mathbf{2 0 1 8}$ & $\mathbf{2 0 1 7}$ & $\mathbf{2 0 1 8}$ \\
\hline & \multicolumn{2}{c}{$\mathrm{mm}$} & & ${ }^{\circ} \mathrm{C}$ \\
April & $157.5(+64.0)$ & $63.5(-30.0)$ & $13.9(+2.8)$ & $7.8(-3.3)$ \\
May & $142.2(+18.0)$ & $106.7(-17.5)$ & $16.1(-0.8)$ & $22.2(+5.3)$ \\
June & $63.5(-46.7)$ & $185.4(+75.2)$ & $22.8(+0.4)$ & $23.9(+1.6)$ \\
July & $55.9(-63.5)$ & $81.3(-38.1)$ & $25.0(+1.2)$ & $23.9(+0.1)$ \\
August & $55.9(-43.9)$ & $101.6(+1.8)$ & $22.2(-0.8)$ & $23.9(+0.9)$ \\
September & $20.3(-59.2)$ & $119.4(39.9)$ & $20.6(+1.6)$ & $21.7(+2.7)$ \\
\hline
\end{tabular}

\subsection{Residue Degradation}

Overwinter residue degradation was influenced by mechanical residue treatment with the chopped treatment enhancing residue decay by $7 \%$ on average (46\% reduction in residue remaining in spring when chopped compared to a 39\% reduction with the standard stalk rollers) (Tables 3 and 4). Other studies have shown similar results of enhanced degradation with reduced residue fragment size $[30,47,48]$. Although not statistically significant, degradation tended to improve with fall chemical applications (i.e., Extract PBA and AMS) compared to that of the untreated control. According to Bender et al. [49], grain yields of $12.22 \mathrm{Mg} \mathrm{ha}^{-1}$ produce $12.1 \mathrm{Mg}$ of residue ha ${ }^{-1}$. Assuming similar yields of the previous corn crop for this study, nutrients tied up within the initial aboveground stover residue would amount to $10.4 \mathrm{~kg} \mathrm{~N}, 2.0 \mathrm{~kg} \mathrm{P}_{2} \mathrm{O}_{5}$, and $11.7 \mathrm{~kg} \mathrm{~K} 2 \mathrm{O}$ per ton of dry matter. Therefore, enhanced residue degradation over winter by sizing (chopping) of the residue could result in an additional $3.4 \mathrm{~kg} \mathrm{~N}, 0.8 \mathrm{~kg} \mathrm{P}_{2} \mathrm{O}_{5}$, and $4.4 \mathrm{~kg} \mathrm{~K}_{2} \mathrm{O}$ ha ${ }^{-1}$ of readily available mineral nutrients at planting (based on the $7 \%$ increase in degradation compared to standard mechanical harvest method). 
Table 3. Tests of fixed sources of variation on corn residue decomposition, seedling emergence, biomass accumulation, and leaf greenness (crop vigor) at various plant growth stages (V6, V8, R2, and R6) as affected by two crop rotations, two mechanical and three chemical residue managements, two input levels, and two hybrids at Champaign, Illinois during 2017 and 2018.

\begin{tabular}{|c|c|c|c|c|c|c|c|c|c|c|}
\hline \multirow[b]{2}{*}{ Source of variation } & \multirow[b]{2}{*}{ \% Residue Decay } & \multicolumn{3}{|c|}{ Emergence } & \multicolumn{3}{|c|}{ Early Season Biomass } & \multicolumn{2}{|c|}{ Leaf Greenness } & \multirow{2}{*}{$\begin{array}{l}\text { Late Bio. } \\
\text { R6 Stover }\end{array}$} \\
\hline & & Days to $50 \%$ & Days to Max & $\%$ of Total & V6 Shoot & V6 Root & V6 Shoot:Root & V8 NDVI & R2 SPAD & \\
\hline & \multicolumn{10}{|c|}{$p>F$} \\
\hline Rotation (R) & 0.6812 & 0.1565 & 0.1274 & 0.2896 & 0.7798 & 0.3565 & 0.3307 & 0.6817 & 0.0012 & 0.3855 \\
\hline Mechanical (M) & 0.0104 & 0.1231 & 0.1027 & 0.0357 & 0.8989 & 0.8234 & 0.6159 & 0.2413 & 0.0427 & 0.4131 \\
\hline $\mathrm{R} \times \mathrm{M}$ & 0.8541 & 0.1536 & 0.5458 & 0.7653 & 0.7196 & 0.2977 & 0.1202 & 0.2439 & 0.9106 & 0.7942 \\
\hline Chemical (C) & 0.1886 & 0.2442 & 0.7839 & 0.8671 & 0.7179 & 0.6631 & 0.2710 & 0.7223 & $<0.0001$ & 0.1952 \\
\hline $\mathrm{R} \times \mathrm{C}$ & 0.4729 & 0.5051 & 0.5261 & 0.2126 & 0.6808 & 0.3519 & 0.0819 & 0.9135 & 0.0347 & 0.7378 \\
\hline $\mathrm{M} \times \mathrm{C}$ & 0.7766 & 0.8607 & 0.6636 & 0.2113 & 0.6340 & 0.3338 & 0.1004 & 0.4169 & 0.7360 & 0.4048 \\
\hline $\mathrm{R} \times \mathrm{M} \times \mathrm{C}$ & 0.9119 & 0.6110 & 0.5060 & 0.3414 & 0.5827 & 0.8952 & 0.5107 & 0.7269 & 0.8304 & 0.3692 \\
\hline Input Level (I) & - & 0.0078 & 0.0109 & 0.0139 & $<0.0001$ & $<0.0001$ & $<0.0001$ & $<0.0001$ & $<0.0001$ & $<0.0001$ \\
\hline $\mathrm{R} \times \mathrm{I}$ & - & 0.1174 & 0.0717 & 0.3504 & 0.2338 & 0.1239 & 0.9293 & 0.7138 & 0.5185 & 0.7990 \\
\hline $\mathrm{M} \times \mathrm{I}$ & - & 0.4878 & 0.5039 & 0.7109 & 0.3153 & 0.7307 & 0.1714 & 0.5235 & 0.6474 & 0.5453 \\
\hline $\mathrm{R} \times \mathrm{M} \times \mathrm{I}$ & - & 0.8226 & 0.4358 & 0.4686 & 0.2733 & 0.7897 & 0.5797 & 0.0003 & 0.6477 & 0.8096 \\
\hline$C \times I$ & - & 0.8893 & 0.2107 & 0.5268 & 0.3702 & 0.4680 & 0.4270 & 0.2499 & 0.0093 & 0.1152 \\
\hline $\mathrm{R} \times \mathrm{C} \times \mathrm{I}$ & - & 0.4751 & 0.9215 & 0.7097 & 0.6078 & 0.4434 & 0.7877 & 0.3800 & 0.4781 & 0.7723 \\
\hline $\mathrm{M} \times \mathrm{C} \times \mathrm{I}$ & - & 0.4113 & 0.2534 & 0.1827 & 0.4753 & 0.5974 & 0.7011 & 0.5125 & 0.7107 & 0.8253 \\
\hline $\mathrm{R} \times \mathrm{M} \times \mathrm{C} \times \mathrm{I}$ & - & 0.2296 & 0.4438 & 0.3848 & 0.9647 & 0.4729 & 0.3453 & 0.4865 & 0.7642 & 0.3777 \\
\hline Hybrid (H) & - & 0.6785 & 0.4773 & 0.1042 & 0.0008 & $<0.0001$ & 0.8358 & $<0.0001$ & 0.0015 & 0.8021 \\
\hline $\mathrm{R} \times \mathrm{H}$ & - & 0.0056 & 0.1715 & 0.9071 & 0.8008 & 0.6464 & 0.6752 & 0.3192 & 0.1637 & 0.5007 \\
\hline $\mathrm{M} \times \mathrm{H}$ & - & 0.7735 & 0.5212 & 0.0043 & 0.7451 & 0.7463 & 0.9703 & 0.9138 & 0.6959 & 0.6208 \\
\hline $\mathrm{R} \times \mathrm{M} \times \mathrm{H}$ & - & 0.2767 & 0.0493 & 0.6248 & 0.8790 & 0.3113 & 0.0672 & 0.4544 & 0.9509 & 0.9819 \\
\hline $\mathrm{C} \times \mathrm{H}$ & - & 0.4975 & 0.2307 & 0.3025 & 0.1030 & 0.0393 & 0.4525 & 0.8564 & 0.2154 & 0.4430 \\
\hline $\mathrm{R} \times \mathrm{C} \times \mathrm{H}$ & - & 0.5981 & 0.0350 & 0.5704 & 0.9346 & 0.7368 & 0.9753 & 0.8950 & 0.1160 & 0.9294 \\
\hline $\mathrm{M} \times \mathrm{C} \times \mathrm{H}$ & - & 0.1025 & 0.1928 & 0.3903 & 0.9740 & 0.3072 & 0.8358 & 0.8778 & 0.2848 & 0.7999 \\
\hline $\mathrm{R} \times \mathrm{M} \times \mathrm{C} \times \mathrm{H}$ & - & 0.2522 & 0.3161 & 0.0773 & 0.7912 & 0.4894 & 0.5227 & 0.9749 & 0.5867 & 0.8895 \\
\hline $\mathrm{I} \times \mathrm{H}$ & - & 0.6150 & 0.5116 & 0.9395 & 0.6930 & 0.5138 & 0.5938 & 0.8513 & 0.3289 & 0.8472 \\
\hline $\mathrm{R} \times \mathrm{I} \times \mathrm{H}$ & - & 0.9843 & 0.9193 & 0.8686 & 0.6646 & 0.2437 & 0.6497 & 0.6629 & 0.6325 & 0.8766 \\
\hline $\mathrm{M} \times \mathrm{I} \times \mathrm{H}$ & - & 0.4878 & 0.2742 & 0.2464 & 0.6651 & 0.7252 & 0.6446 & 0.8705 & 0.7563 & 0.4796 \\
\hline $\mathrm{R} \times \mathrm{M} \times \mathrm{I} \times \mathrm{H}$ & - & 0.4662 & 0.0378 & 0.2528 & 0.7776 & 0.2767 & 0.9096 & 0.5229 & 0.8730 & 0.3123 \\
\hline $\mathrm{C} \times \mathrm{I} \times \mathrm{H}$ & - & 0.2907 & 0.4613 & 0.6272 & 0.0119 & 0.0118 & 0.6771 & 0.8874 & 0.3353 & 0.7815 \\
\hline $\mathrm{R} \times \mathrm{C} \times \mathrm{I} \times \mathrm{H}$ & - & 0.0213 & 0.9876 & 0.7396 & 0.1128 & 0.2934 & 0.6651 & 0.3724 & 0.8353 & 0.2942 \\
\hline $\mathrm{M} \times \mathrm{C} \times \mathrm{I} \times \mathrm{H}$ & - & 0.6544 & 0.0127 & 0.4734 & 0.9593 & 0.9025 & 0.4283 & 0.8308 & 0.3338 & 0.9325 \\
\hline $\mathrm{R} \times \mathrm{M} \times \mathrm{C} \times \mathrm{I} \times \mathrm{H}$ & - & 0.7251 & 0.3065 & 0.2320 & 0.9253 & 0.3776 & 0.2107 & 0.6780 & 0.8806 & 0.2254 \\
\hline
\end{tabular}


Table 4. Corn residue degradation over winter as influenced by rotation and mechanical or chemical residue management. Data represent the reduction in dry matter weight of the initial residue subsamples from the previous season post-harvest (fall 2016 and 2017) versus the weight remaining preplant (spring 2017 and 2018) in field-located mesh bags at Champaign, IL.

\begin{tabular}{ccc}
\hline & \multicolumn{2}{c}{ Mechanical Residue Management $\S$} \\
\cline { 2 - 3 } Rotation $+/$ Chemical Residue Management. $\ddagger$ & Standard & Chopped \\
\hline Continuous Corn & \multicolumn{2}{c}{ \% Reduction } \\
Untreated & 34 & 43 \\
Extract PBA & 40 & 43 \\
AMS & 42 & 49 \\
Corn-Soybean & & 47 \\
Untreated & 39 & 46 \\
Extract PBA & 40 & 49 \\
AMS & 40 & \\
\hline
\end{tabular}

$†$ Rotation LSD $(p \leq 0.10)=$ nonsignificant (NS). ‡ Chemical residue management LSD $(p \leq 0.10)=$ NS. § Mechanical residue management LSD $(p \leq 0.10)=4 \%$. AMS: ammonium sulfate.

\subsection{Seedling Emergence}

Time to $50 \%$ emergence and total emergence was similar for continuous corn and corn in rotation with soybean as well as when grown in standard or chopped corn residue (Table 5). Conversely, findings from Mehdi et al. [17] and Blanco-Canqui et al. [19] documented slower emergence with increased surface residue, and we speculate that the conventional tillage implemented within our trial helped overcome the obstacle of the sheer volume of corn residue at planting. Meese et al. reported similar emergence with rotated and continuous corn when grown in conventional tillage compared to delayed emergence of continuous corn when grown in no-tillage conditions [4]. In the current study, high input management increased the time to $50 \%$ emergence by 0.2 days and total emergence by 0.6 days compared to when grown with standard input. This emergence delay could have been from the addition of potassium fertilizer as potassium chloride $(\mathrm{KCl})$, which has the highest salt index compared to other common fertilizer sources [25]. In the laboratory, Ouyang et al. found, with additions of $\mathrm{KCl}$, corn seedling germination was delayed, and with triple superphosphate (TSP), germination was unaffected [50].

When comparing the known seed number planted within a $305 \mathrm{~cm}$ row section to the total emerged, the average percent emergence was $94 \%$ (Table 5). Percent seedling emergence was improved with chopped mechanical residue management compared to standard ( $95 \%$ compared to $94 \%$ ), and Sindelar et al. reported similar results after residue was chopped and 79\% was removed [51]. At completion of seedling emergence, the high input level led to slightly a lower percentage of emerged plants than standard agronomic management. 
Table 5. Days to $50 \%$ and maximum emergence and percentage of total emerged at completion of emergence as influenced by crop rotation, mechanical and chemical residue management, input level, and corn hybrid when grown at Champaign, IL during 2017 and 2018.

\begin{tabular}{|c|c|c|c|c|c|}
\hline Input Level & Hybrid & Chemical & $\begin{array}{l}\text { Days to } 50 \% \\
\text { Emergence }\end{array}$ & $\begin{array}{l}\text { Days to Max } \\
\text { Emergence }\end{array}$ & $\begin{array}{c}\text { Percent Emerged at Total } \\
\text { Emergence }\end{array}$ \\
\hline & & & ys after planti & $\%$ & \\
\hline \multicolumn{6}{|c|}{ Continuous Corn-Standard Residue Management. } \\
\hline \multirow[t]{6}{*}{ Standard } & $6110 S S$ & Untreated & 14.4 & 19.1 & 95.4 \\
\hline & & Extract PBA & 14.3 & 18.9 & 95.4 \\
\hline & & AMS † & 14.6 & 19.6 & 96.6 \\
\hline & 6594SS & Untreated & 14.4 & 18.0 & 96.6 \\
\hline & & Extract PBA & 14.4 & 16.6 & 91.4 \\
\hline & & AMS & 14.3 & 17.5 & 92.8 \\
\hline \multirow{6}{*}{ Intensive } & 6110SS & Untreated & 14.6 & 18.7 & 93.5 \\
\hline & & Extract PBA & 14.5 & 18.0 & 97.7 \\
\hline & & AMS & 14.6 & 18.4 & 93.1 \\
\hline & $6594 S S$ & Untreated & 14.4 & 19.4 & 95.8 \\
\hline & & Extract PBA & 14.3 & 18.5 & 92.1 \\
\hline & & AMS & 14.1 & 17.7 & 89.4 \\
\hline \multicolumn{6}{|c|}{ Continuous Corn-Chopped Residue Management } \\
\hline \multirow[t]{6}{*}{ Standard } & 6110SS & Untreated & 14.6 & 17.8 & 97.4 \\
\hline & & Extract PBA & 14.5 & 17.4 & 96.1 \\
\hline & & AMS & 14.1 & 18.9 & 92.8 \\
\hline & $6594 S S$ & Untreated & 14.1 & 18.4 & 97.4 \\
\hline & & Extract PBA & 14.3 & 20.2 & 95.1 \\
\hline & & AMS & 14.4 & 18.8 & 95.4 \\
\hline \multirow[t]{6}{*}{ Intensive } & 6110SS & Untreated & 14.5 & 19.6 & 94.4 \\
\hline & & Extract PBA & 14.6 & 18.5 & 94.9 \\
\hline & & AMS & 14.3 & 18.4 & 94.9 \\
\hline & 6594SS & Untreated & 14.6 & 18.4 & 94.0 \\
\hline & & Extract PBA & 14.3 & 18.6 & 94.0 \\
\hline & & AMS & 14.4 & 19.1 & 97.7 \\
\hline \multicolumn{6}{|c|}{ Corn-Soybean Rotation-Standard Residue Management } \\
\hline \multirow[t]{6}{*}{ Standard } & 6110SS & Untreated & 14.1 & 17.4 & 92.8 \\
\hline & & Extract PBA & 14.9 & 18.1 & 97.4 \\
\hline & & AMS & 14.4 & 17.8 & 93.4 \\
\hline & $6594 S S$ & Untreated & 15.3 & 19.1 & 92.1 \\
\hline & & Extract PBA & 14.9 & 18.3 & 93.3 \\
\hline & & AMS & 14.2 & 18.8 & 92.9 \\
\hline \multirow[t]{6}{*}{ Intensive } & 6110SS & Untreated & 14.8 & 17.5 & 93.5 \\
\hline & & Extract PBA & 14.8 & 20.3 & 96.3 \\
\hline & & AMS & 14.6 & 20.3 & 93.3 \\
\hline & 6594SS & Untreated & 15.1 & 20.9 & 88.4 \\
\hline & & Extract PBA & 14.8 & 20.3 & 91.2 \\
\hline & & AMS & 15.1 & 19.1 & 91.0 \\
\hline \multicolumn{6}{|c|}{ Corn-Soybean Rotation-Chopped Residue Management } \\
\hline \multirow[t]{6}{*}{ Standard } & $6110 S S$ & Untreated & 14.1 & 17.3 & 98.0 \\
\hline & & Extract PBA & 14.4 & 19.8 & 94.1 \\
\hline & & AMS & 14.3 & 20.9 & 96.1 \\
\hline & 6594SS & Untreated & 14.6 & 19.3 & 94.6 \\
\hline & & Extract PBA & 14.3 & 18.4 & 96.1 \\
\hline & & AMS & 14.3 & 19.7 & 95.9 \\
\hline \multirow[t]{6}{*}{ Intensive } & 6110SS & Untreated & 14.8 & 20.4 & 89.4 \\
\hline & & Extract PBA & 14.8 & 20.6 & 91.2 \\
\hline & & AMS & 14.4 & 18.0 & 95.4 \\
\hline & 6594SS & Untreated & 14.4 & 20.5 & 96.3 \\
\hline & & Extract PBA & 15.0 & 18.8 & 93.2 \\
\hline & & AMS & 14.8 & 21.4 & 93.7 \\
\hline \multicolumn{3}{|c|}{ Rotation LSD $(p \leq 0.10)$} & NS $\ddagger$ & NS & NS \\
\hline \multicolumn{3}{|c|}{ Mechanical Residue Management LSD $(p \leq 0.10)$} & NS & NS & 1.2 \\
\hline \multicolumn{3}{|c|}{ Chemical Residue Management LSD $(p \leq 0.10)$} & NS & NS & NS \\
\hline \multicolumn{3}{|c|}{ Input Level LSD $(p \leq 0.10)$} & 0.1 & 0.5 & 1.1 \\
\hline \multicolumn{3}{|c|}{ Hybrid LSD $(p \leq 0.10)$} & NS & NS & NS \\
\hline
\end{tabular}

† AMS, ammonium sulfate. $\ddagger$ NS, nonsignificant. 


\subsection{Plant Biomass Accumulation and Plant Health Assessment}

Agronomic input level and hybrid both significantly impacted above- and below-ground early season (V6 growth stage) biomass accumulation (Tables 3 and 6), similar to previously documented increases in early season biomass accumulation of corn with increased fertilizer inputs [52,53]. In this study, compared to the standard management, the intensive management led to $71 \%$ greater aboveground ( $427 \mathrm{~kg} \mathrm{ha}^{-1}$ versus $732 \mathrm{~kg} \mathrm{ha}^{-1}$ ) and $58 \%$ greater belowground biomass accumulation (88 $\mathrm{kg} \mathrm{ha}^{-1}$ versus $139 \mathrm{~kg} \mathrm{ha}^{-1}$ ) (Table 6). Since this V6 sampling occurred immediately after the additional sidedressed nitrogen, agronomic management responses were primarily from the broadcasted Aspire and banded MicroEssentials SZ at planting. On an individual plant basis, weight increased by $1.6 \mathrm{~g} \mathrm{plant}^{-1}$ above- $\left(7.3\right.$ versus $5.7 \mathrm{~g} \mathrm{plant}^{-1}$ ) and $0.2 \mathrm{~g} \mathrm{plant}^{-1}$ below-ground (1.4 versus $1.2 \mathrm{~g} \mathrm{plant}^{-1}$ ) from high input versus standard agronomic management (data not shown). Shoot biomass accumulation was less with hybrid 6110SS compared to 6594SS (557 $\mathrm{kg} \mathrm{ha}^{-1}$ compared to $\left.602 \mathrm{~kg} \mathrm{ha}^{-1}\right)$, along with root biomass accumulation (107 $\mathrm{kg} \mathrm{ha}^{-1}$ compared to $120 \mathrm{~kg} \mathrm{ha}^{-1}$ ) (Table 6). Crop rotation did not affect above- or below-ground biomass accumulations, similar to data previously reported by Crookston et al. [54]. Shoot to root ratios were greatest when plants were grown in the intensive management system, and although both shoot and root biomass were greater with the high input level compared to standard, the magnitude of gain was greater aboveground (Table 6).

No difference was detected in V8 canopy greenness from crop rotation or residue management treatments (Table 6). This lack of early season difference from residue management agrees with results obtained in conventional tillage with partially removed and sized corn residue versus retained [51]. Canopy greenness at the V8 growth stage increased by $14 \%$ from the intensive input level (average NDVI of 0.65 with intensive input compared to 0.57 with standard input) (Table 6). Additionally, hybrid impacted canopy greenness with hybrid 6110SS exhibiting an NDVI of 0.60 versus hybrid 6594SS at 0.62. Shanahan et al. also reported NDVI variation with hybrid and nitrogen input variations [55].

At the R2 growth stage, ear leaf greenness was altered by rotation, mechanical and chemical residue managements, input level, and hybrid (Table 3). The corn-soybean rotation led to enhanced ear leaf greenness compared to continuous corn (58.6 versus 55.3 SPAD relative units, respectively) (Table 6). Similar rotational responses of leaf chlorophyll concentration were documented at V10 (ten fully formed leaves) [56] and R2/R3 (kernel blister stage/kernel milk stage) [2,56,57]. This difference in leaf chlorophyll could be attributed to improved $\mathrm{N}$ availability, and even though soybean production removed nitrogen from the soil [58,59], the majority of nitrogen in the soybean residue that remained at harvest was taken up by the subsequent crop [60]. Additionally, cumulative mineralization of nitrogen was less with continuous corn compared to the corn-soybean rotation during the V10 to R2 growth stages, which are critical for nitrogen uptake [28].

Plants that grew in chopped corn residue had increased ear leaf greenness compared to standard-processed residue (Table 6). Leaf chlorophyll concentration, photosynthetic potential of the plant, and leaf $\mathrm{N}$ nutrient status have been shown to be closely associated [61,62]. Cropping system and mechanical residue management treatment-induced differences in leaf chlorophyll suggest that $\mathrm{N}$ uptake and $\mathrm{N}$ availability play critical roles in the continuous corn yield penalty and indicate potential ways to help mitigate it.

Although there was additional fertility and foliar protection, intensive management reduced leaf greenness (SPAD readings), likely due to the increased planting population (Table 6). Hashemi-Dezfouli and Herbert [63] and Vogel and Below [2] documented significant reductions in leaf chlorophyll levels as population density increased. Furthermore, nitrogen additions did not mitigate reduced SPAD readings (assessed 90 days after planting) induced by increased planting population in research investigating nitrogen by population interactions [64]. Hybrid selection also impacted R2 measurements, with the higher-yielding 6110SS having higher levels of greenness (57.4 SPAD relative units) than the lower-yielding 6594SS with lower values (56.6 SPAD relative units). Previous studies have also documented genetic variation in leaf chlorophyll levels $[55,65,66]$. 
Table 6. Above- and below-ground biomass accumulation, plant greenness, and harvest index (HI) as influenced by crop rotation, mechanical and chemical residue management, agronomic input level, and hybrid at various plant growth stages (V6, V8, R2, and R6) for corn grown at Champaign, IL during 2017 and 2018. All values are reported at $0 \mathrm{~g} \mathrm{~kg}^{-1}$ moisture concentration.

\begin{tabular}{|c|c|c|c|c|c|c|c|c|c|}
\hline \multirow[b]{2}{*}{ Input Level } & \multirow[b]{2}{*}{ Hybrid } & \multirow[b]{2}{*}{ Chemical } & \multicolumn{3}{|c|}{ Early Season Biomass } & \multicolumn{2}{|c|}{ Leaf Greenness } & \multicolumn{2}{|c|}{ Late Biomass } \\
\hline & & & $\begin{array}{c}\text { V6 } \\
\text { Shoot }\end{array}$ & $\begin{array}{c}\text { V6 } \\
\text { Root }\end{array}$ & $\begin{array}{c}\text { V6 } \\
\text { Shoot:Root }\end{array}$ & $\begin{array}{c}\text { V8 } \\
\text { NDVI }\end{array}$ & $\begin{array}{c}\text { R2 } \\
\text { SPAD }\end{array}$ & $\begin{array}{c}\text { R6 } \\
\text { Stover }\end{array}$ & HI \\
\hline \multicolumn{8}{|c|}{$\mathrm{kg} \mathrm{ha}^{-1}$} & $\mathrm{~kg} \mathrm{ha}^{-1}$ & $\%$ \\
\hline \multicolumn{10}{|c|}{ Continuous Corn-Standard Residue Management } \\
\hline \multirow[t]{6}{*}{ Standard } & \multirow[t]{3}{*}{$6110 S S$} & Untreated & 385 & 79 & 4.9 & 0.55 & 56.2 & 8424 & 55.3 \\
\hline & & Extract PBA & 440 & 86 & 5.1 & 0.57 & 55.9 & 7774 & 55.8 \\
\hline & & AMS + & 348 & 71 & 4.9 & 0.56 & 57.8 & 8101 & 56.3 \\
\hline & \multirow[t]{3}{*}{ 6594SS } & Untreated & 424 & 95 & 4.4 & 0.59 & 54.3 & 8027 & 54.0 \\
\hline & & Extract PBA & 436 & 86 & 5.1 & 0.60 & 55.8 & 8045 & 54.8 \\
\hline & & AMS & 465 & 94 & 4.9 & 0.59 & 58.2 & 7637 & 56.5 \\
\hline \multirow{6}{*}{ Intensive } & \multirow[t]{3}{*}{ 6110SS } & Untreated & 723 & 141 & 5.1 & 0.62 & 53.2 & 10198 & 54.3 \\
\hline & & Extract PBA & 678 & 124 & 5.5 & 0.62 & 54.5 & 10688 & 53.4 \\
\hline & & AMS & 766 & 151 & 5.1 & 0.62 & 55.4 & 9705 & 55.5 \\
\hline & \multirow[t]{3}{*}{ 6594SS } & Untreated & 764 & 147 & 5.2 & 0.65 & 51.7 & 10025 & 53.0 \\
\hline & & Extract PBA & 818 & 160 & 5.1 & 0.66 & 53.5 & 11193 & 51.8 \\
\hline & & AMS & 683 & 134 & 5.1 & 0.66 & 53.5 & 10396 & 52.9 \\
\hline & & Cont & us Corn & loppe & sidue Manag & nent & & & \\
\hline Standard & 6110SS & Untreated & 384 & 76 & 5.0 & 0.55 & 55.7 & 8550 & 56.1 \\
\hline & & Extract PBA & 399 & 74 & 5.4 & 0.54 & 57.0 & 7082 & 59.6 \\
\hline & & AMS & 395 & 83 & 4.8 & 0.55 & 59.2 & 7747 & 57.9 \\
\hline & 6594SS & Untreated & 411 & 88 & 4.7 & 0.58 & 55.8 & 8469 & 55.1 \\
\hline & & Extract PBA & 416 & 86 & 4.8 & 0.58 & 55.0 & 8500 & 54.4 \\
\hline & & AMS & 485 & 99 & 4.9 & 0.57 & 58.2 & 7920 & 57.4 \\
\hline Intensive & 6110SS & Untreated & 742 & 127 & 5.9 & 0.64 & 54.8 & 10195 & 55.8 \\
\hline & & Extract PBA & 635 & 120 & 5.3 & 0.64 & 55.5 & 11232 & 53.3 \\
\hline & & AMS & 731 & 132 & 5.5 & 0.64 & 55.3 & 10703 & 54.3 \\
\hline & 6594SS & Untreated & 783 & 156 & 5.0 & 0.66 & 53.5 & 10945 & 53.3 \\
\hline & & Extract PBA & 808 & 154 & 5.3 & 0.67 & 53.8 & 10462 & 54.8 \\
\hline & & AMS & 709 & 141 & 5.1 & 0.67 & 54.1 & 10550 & 53.8 \\
\hline & & Corn-So & In Rotat & -Stanc & Residue Ma & gement & & & \\
\hline Standard & 6110SS & Untreated & 423 & 86 & 4.9 & 0.57 & 59.4 & 8616 & 57.1 \\
\hline & & Extract PBA & 401 & 75 & 5.3 & 0.55 & 59.5 & 8360 & 58.3 \\
\hline & & AMS & 444 & 84 & 5.3 & 0.56 & 59.5 & 8187 & 58.3 \\
\hline & 6594SS & Untreated & 490 & 107 & 4.6 & 0.58 & 57.6 & 7885 & 57.2 \\
\hline & & Extract PBA & 477 & 102 & 4.7 & 0.59 & 59.9 & 8729 & 56.2 \\
\hline & & AMS & 456 & 87 & 5.3 & 0.59 & 60.4 & 8411 & 56.9 \\
\hline Intensive & 6110SS & Untreated & 712 & 134 & 5.3 & 0.63 & 57.6 & 10422 & 57.1 \\
\hline & & Extract PBA & 671 & 135 & 5.0 & 0.65 & 56.8 & 10770 & 56.3 \\
\hline & & AMS & 710 & 127 & 5.6 & 0.65 & 57.9 & 11368 & 54.5 \\
\hline & 6594SS & Untreated & 683 & 132 & 5.2 & 0.66 & 56.5 & 10195 & 55.7 \\
\hline & & Extract PBA & 789 & 170 & 4.6 & 0.67 & 58.1 & 11042 & 55.9 \\
\hline & & AMS & 699 & 126 & 5.5 & 0.66 & 56.2 & 10560 & 55.7 \\
\hline & & Corn-So & n Rotati & -Chop & Residue Ma & gement & & & \\
\hline Standard & 6110SS & Untreated & 341 & 70 & 4.9 & 0.58 & 59.6 & 8515 & 58.4 \\
\hline & & Extract PBA & 403 & 92 & 4.4 & 0.56 & 59.8 & 8447 & 58.2 \\
\hline & & AMS & 457 & 89 & 5.2 & 0.55 & 61.6 & 8204 & 58.8 \\
\hline & 6594SS & Untreated & 429 & 113 & 3.8 & 0.60 & 59.0 & 8642 & 56.5 \\
\hline & & Extract PBA & 450 & 93 & 4.8 & 0.60 & 60.4 & 8323 & 57.9 \\
\hline & & AMS & 480 & 97 & 4.9 & 0.57 & 60.1 & 8267 & 56.7 \\
\hline Intensive & 6110SS & Untreated & 725 & 134 & 5.4 & 0.62 & 58.2 & 11219 & 54.2 \\
\hline & & Extract PBA & 720 & 134 & 5.4 & 0.63 & 57.6 & 11228 & 54.7 \\
\hline & & AMS & 734 & 145 & 5.0 & 0.63 & 58.8 & 10174 & 57.0 \\
\hline & 6594SS & Untreated & 735 & 141 & 5.2 & 0.64 & 57.3 & 10671 & 54.8 \\
\hline & & Extract PBA & 815 & 149 & 5.5 & 0.65 & 58.8 & 11849 & 54.2 \\
\hline & & AMS & 734 & 131 & 5.6 & 0.66 & 56.7 & 10124 & 57.6 \\
\hline & tion LSD & $0.10)$ & NS $\ddagger$ & NS & NS & NS & 1.2 & NS & 1.0 \\
\hline Mechanice & $\begin{array}{l}\text { Residue } \mathrm{M} \\
\quad(p \leq 0.1\end{array}$ & gement LSD & NS & NS & NS & NS & 0.5 & NS & NS \\
\hline Chemical & $\begin{array}{l}\text { esidue } \mathrm{M}_{c} \\
(p \leq 0.1\end{array}$ & yement LSD & NS & NS & NS & NS & 0.5 & NS & NS \\
\hline Inps & Level LSD & $\leq 0.10)$ & 21 & 4 & 0.1 & 0.01 & 0.4 & 265 & 0.6 \\
\hline & rid LSD ( & $0.10)$ & 21 & 4 & NS & 0.01 & 0.4 & NS & 0.6 \\
\hline
\end{tabular}

† AMS, ammonium sulfate. $\ddagger$ NS, nonsignificant. 
Fall chemical treatments to the residue increased ear leaf greenness compared to the untreated control, with the largest positive responses to AMS and Extract PBA occurring in continuous corn compared to rotated corn (Table 6). At the R2 growth stage, SPAD readings of rotation by chemical treatments followed this pattern: rotated corn with fall AMS (58.9 SPAD relative units) = rotated corn with fall Extract PBA (58.9 SPAD relative units) $>$ rotated corn with no fall application (58.2 SPAD relative units) $>$ continuous corn with fall AMS (56.5 SPAD relative units) > continuous corn with fall Extract PBA (55.1 SPAD relative units) > continuous corn with no fall application (54.4 SPAD relative units).

Stover biomass accumulation at the R6 growth stage was 30\% greater when plants were grown in the intensive management compared to the standard input level $\left(10,663 \mathrm{~kg} \mathrm{ha}^{-1}\right.$ compared to $8202 \mathrm{~kg} \mathrm{ha}^{-1}$ ) (Table 6). On an individual plant basis, the standard input level led to an additional $4 \mathrm{~g}$ plant $^{-1}$ in dry weight (109 $\mathrm{g}$ plant $^{-1}$ with standard input versus $105 \mathrm{~g}$ plant $^{-1}$ with high input; data not shown). However, the intensive input level had 32,000 more plants ha ${ }^{-1}$, resulting in an increased overall biomass production. Although Sindelar et al. reported that more stover dry matter was accumulated at harvest with corn rotated with soybean 75\% of the time [67], the current study resulted in similar stover levels produced in continuous and rotated corn with the latter exhibiting only a tendency to increase stover accumulation.

\subsection{Grain Yield and Harvest Index}

Crop rotation, mechanical residue management, input level, and hybrid all significantly influenced grain yield (Table 7). When averaged across all other treatments, the CCYP associated with 15th year continuous corn compared to first year corn following soybean decreased yield by $1.30 \mathrm{Mg} \mathrm{ha}^{-1}(p=0.0002)$ (Table 8).

Table 7. Tests of fixed sources of variation on corn grain yield, harvest index, yield components, and grain quality as affected by two crop rotations, two mechanical and three chemical residue managements, two input levels, and two hybrids at Champaign, Illinois during 2017 and 2018.

\begin{tabular}{|c|c|c|c|c|c|c|c|}
\hline \multirow[b]{2}{*}{ Source of Variation } & \multirow[b]{2}{*}{ Yield } & \multirow[b]{2}{*}{ Harvest Index } & \multicolumn{2}{|c|}{ Yield Component } & \multicolumn{3}{|c|}{ Grain Quality } \\
\hline & & & Kernel Number & Kernel Weight & Oil & Protein & Starch \\
\hline & & & & $p>\mathrm{F}$ & & & \\
\hline Rotation (R) & 0.0002 & 0.0214 & 0.0010 & 0.0015 & 0.3341 & 0.0779 & 0.0806 \\
\hline Mechanical (M) & 0.0818 & 0.1879 & 0.0082 & 0.5783 & 0.1382 & 0.0357 & 0.9907 \\
\hline $\mathrm{R} \times \mathrm{M}$ & 0.1936 & 0.1836 & 0.2202 & 0.4137 & 0.2912 & 0.1322 & 0.3406 \\
\hline Chemical (C) & 0.6004 & 0.1956 & 0.5321 & 0.4623 & 0.0018 & 0.1571 & 0.0495 \\
\hline $\mathrm{R} \times \mathrm{C}$ & 0.2558 & 0.8874 & 0.0819 & 0.8843 & 0.5450 & 0.1645 & 0.7453 \\
\hline $\mathrm{M} \times \mathrm{C}$ & 0.6235 & 0.6744 & 0.7391 & 0.3476 & 0.6565 & 0.9027 & 0.9584 \\
\hline $\mathrm{R} \times \mathrm{M} \times \mathrm{C}$ & 0.5092 & 0.2593 & 0.3432 & 0.8542 & 0.1502 & 0.2285 & 0.5909 \\
\hline Input Level (I) & $<0.0001$ & $<0.0001$ & $<0.0001$ & 0.0042 & 0.4969 & 0.0006 & 0.1146 \\
\hline $\mathrm{R} \times \mathrm{I}$ & 0.2937 & 0.6228 & 0.2845 & 0.0141 & 0.6696 & 0.0889 & 0.3000 \\
\hline $\mathrm{M} \times \mathrm{I}$ & 0.8738 & 0.3413 & 0.3870 & 0.3129 & 0.6078 & 0.3458 & 0.1818 \\
\hline $\mathrm{R} \times \mathrm{M} \times \mathrm{I}$ & 0.5914 & 0.8535 & 0.8231 & 0.6203 & 0.2152 & 0.7580 & 0.3918 \\
\hline $\mathrm{C} \times \mathrm{I}$ & 0.4971 & 0.4108 & 0.9579 & 0.2279 & 0.2383 & 0.4203 & 0.6573 \\
\hline $\mathrm{R} \times \mathrm{C} \times \mathrm{I}$ & 0.5739 & 0.4513 & 0.8496 & 0.4125 & 0.6202 & 0.5090 & 0.5270 \\
\hline $\mathrm{M} \times \mathrm{C} \times \mathrm{I}$ & 0.7787 & 0.6162 & 0.6233 & 0.8912 & 0.3953 & 0.9670 & 0.5033 \\
\hline $\mathrm{R} \times \mathrm{M} \times \mathrm{C} \times \mathrm{I}$ & 0.4934 & 0.1940 & 0.4328 & 0.8470 & 0.1911 & 0.3985 & 0.1818 \\
\hline Hybrid (H) & 0.0014 & 0.0078 & $<0.0001$ & $<0.0001$ & 0.0059 & $<0.0001$ & 0.0318 \\
\hline $\mathrm{R} \times \mathrm{H}$ & 0.6079 & 0.3514 & 0.3422 & 0.9809 & 0.4951 & 0.0923 & 0.5322 \\
\hline $\mathrm{M} \times \mathrm{H}$ & 0.4555 & 0.9742 & 0.0998 & 0.5765 & 0.3407 & 0.8541 & 0.2341 \\
\hline $\mathrm{R} \times \mathrm{M} \times \mathrm{H}$ & 0.9513 & 0.8715 & 0.5490 & 0.4131 & 0.9359 & 0.8246 & 0.5854 \\
\hline $\mathrm{C} \times \mathrm{H}$ & 0.1805 & 0.8000 & 0.1417 & 0.4084 & 0.5192 & 0.8141 & 0.7864 \\
\hline $\mathrm{R} \times \mathrm{C} \times \mathrm{H}$ & 0.8534 & 0.9714 & 0.2120 & 0.1660 & 0.2290 & 0.9228 & 0.4422 \\
\hline $\mathrm{M} \times \mathrm{C} \times \mathrm{H}$ & 0.9007 & 0.9775 & 0.7812 & 0.8685 & 0.8440 & 0.7883 & 0.8506 \\
\hline $\mathrm{R} \times \mathrm{M} \times \mathrm{C} \times \mathrm{H}$ & 0.9678 & 0.7207 & 0.9848 & 0.9330 & 0.5710 & 0.8026 & 0.5981 \\
\hline $\mathrm{I} \times \mathrm{H}$ & 0.1618 & 0.2828 & 0.7569 & 0.0002 & 0.0057 & 0.1305 & 0.0018 \\
\hline $\mathrm{R} \times \mathrm{I} \times \mathrm{H}$ & 0.5361 & 0.5021 & 0.9173 & 0.3873 & 0.2282 & 0.9451 & 0.2495 \\
\hline $\mathrm{M} \times \mathrm{I} \times \mathrm{H}$ & 0.5865 & 0.2448 & 0.4981 & 0.9788 & 0.8698 & 0.1793 & 0.5334 \\
\hline $\mathrm{R} \times \mathrm{M} \times \mathrm{I} \times \mathrm{H}$ & 0.5621 & 0.4477 & 0.4409 & 0.7780 & 0.2113 & 0.1547 & 0.2559 \\
\hline $\mathrm{C} \times \mathrm{I} \times \mathrm{H}$ & 0.9776 & 0.5457 & 0.9540 & 0.9980 & 0.7654 & 0.9979 & 0.5890 \\
\hline $\mathrm{R} \times \mathrm{C} \times \mathrm{I} \times \mathrm{H}$ & 0.8853 & 0.2224 & 0.7447 & 0.9772 & 0.3482 & 0.5545 & 0.8929 \\
\hline $\mathrm{M} \times \mathrm{C} \times \mathrm{I} \times \mathrm{H}$ & 0.8689 & 0.9217 & 0.3573 & 0.6877 & 0.9897 & 0.9136 & 0.3539 \\
\hline $\mathrm{R} \times \mathrm{M} \times \mathrm{C} \times \mathrm{I} \times \mathrm{H}$ & 0.7555 & 0.1204 & 0.6109 & 0.9910 & 0.7726 & 0.8401 & 0.7851 \\
\hline
\end{tabular}


Table 8. Corn grain yield for two hybrids as influenced by crop rotation, mechanical and chemical residue management, and agronomic input level. Hybrids were grown in continuous corn ( $15^{\text {th }}$ year) and following soybean rotations at Champaign, IL in 2017 and 2018. All values are reported at $0 \mathrm{~g} \mathrm{~kg}^{-1}$ moisture concentration.

\begin{tabular}{|c|c|c|c|c|c|c|c|c|}
\hline & \multicolumn{8}{|c|}{ Crop Rotation $\S$} \\
\hline & \multicolumn{4}{|c|}{ Continuous Corn } & \multicolumn{4}{|c|}{ Corn-Soybean } \\
\hline & \multicolumn{4}{|c|}{ Mechanical Residue Management II } & \multicolumn{4}{|c|}{ Mechanical Residue Management } \\
\hline & \multicolumn{2}{|c|}{ Standard } & \multicolumn{2}{|c|}{ Chopped } & \multicolumn{2}{|c|}{ Standard } & \multicolumn{2}{|c|}{ Chopped } \\
\hline Hybrid t/ & \multicolumn{2}{|c|}{ Input Level \# } & \multicolumn{2}{|c|}{ Input Level } & \multicolumn{2}{|c|}{ Input Level } & \multicolumn{2}{|c|}{ Input Level } \\
\hline Chemical Residue Management $\ddagger$ & Standard & Intensive & Standard & Intensive & Standard & Intensive & Standard & Intensive \\
\hline & \multicolumn{8}{|c|}{$\mathrm{Mg} \mathrm{ha}^{-1}$} \\
\hline 6110SS & & & & & & & & \\
\hline Untreated & 10.23 & 11.87 & 10.77 & 12.68 & 11.43 & 13.72 & 11.83 & 13.24 \\
\hline Extract PBA & 9.77 & 12.02 & 10.33 & 12.45 & 11.62 & 13.63 & 11.53 & 13.49 \\
\hline AMS & 10.43 & 12.00 & 10.56 & 12.27 & 11.27 & 13.50 & 11.56 & 13.48 \\
\hline \multicolumn{9}{|l|}{ 6594SS } \\
\hline Untreated & 9.34 & 11.20 & 10.15 & 12.35 & 10.62 & 12.96 & 11.10 & 12.95 \\
\hline Extract PBA & 9.51 & 11.80 & 9.98 & 12.21 & 11.23 & 13.93 & 11.34 & 13.85 \\
\hline AMS & 9.79 & 11.67 & 10.22 & 12.06 & 10.97 & 13.07 & 10.77 & 13.83 \\
\hline
\end{tabular}

† Hybrid LSD $(p \leq 0.10)=0.19 \mathrm{Mg} \mathrm{ha}^{-1}$. ‡ Chemical Residue Management LSD $(p \leq 0.10)=$ nonsignificant (NS). § Rotation LSD ( $\left.p \leq 0.10\right)=0.37 \mathrm{Mg}$ ha ${ }^{-1}$. II Mechanical Residue Management LSD $(p \leq 0.10)=0.29 \mathrm{Mg} \mathrm{ha}^{-1}$. \# Input level LSD $(p \leq 0.10)=0.19 \mathrm{Mg} \mathrm{ha}^{-1}$. 
Mechanical residue treatments generated visual differences in residue size after harvest (Figure 1A,B) and in-season residue quantity on the soil surface the following year (Figure 1C,D). When averaged over hybrids, chemical residue management, and agronomic management levels, chopped residue management increased yield by $0.53 \mathrm{Mg} \mathrm{ha}^{-1}$ in continuous corn but by only $0.08 \mathrm{Mg} \mathrm{ha}^{-1}$ in the rotated fields (Table 8). With standard agronomic management, mechanically sizing the residue alone (no chemical application) improved corn grain yield by $0.58 \mathrm{Mg} \mathrm{ha}^{-1}$, while the chemical residue management had no effect on grain yield. Hybrid 6594SS tended to respond positively to fall chemical applications to the previous residue with a $0.21 \mathrm{Mg} \mathrm{ha}^{-1}$ yield increase after the AMS treatment and a $0.40 \mathrm{Mg} \mathrm{ha}^{-1}$ response to Extract PBA-treated residue; however, hybrid 6110SS did not respond positively to either chemical management treatment with yield trends of $-0.09 \mathrm{Mg} \mathrm{ha}^{-1}$ and $-0.12 \mathrm{Mg} \mathrm{ha}^{-1}$ with AMS and Extract PBA, respectively.

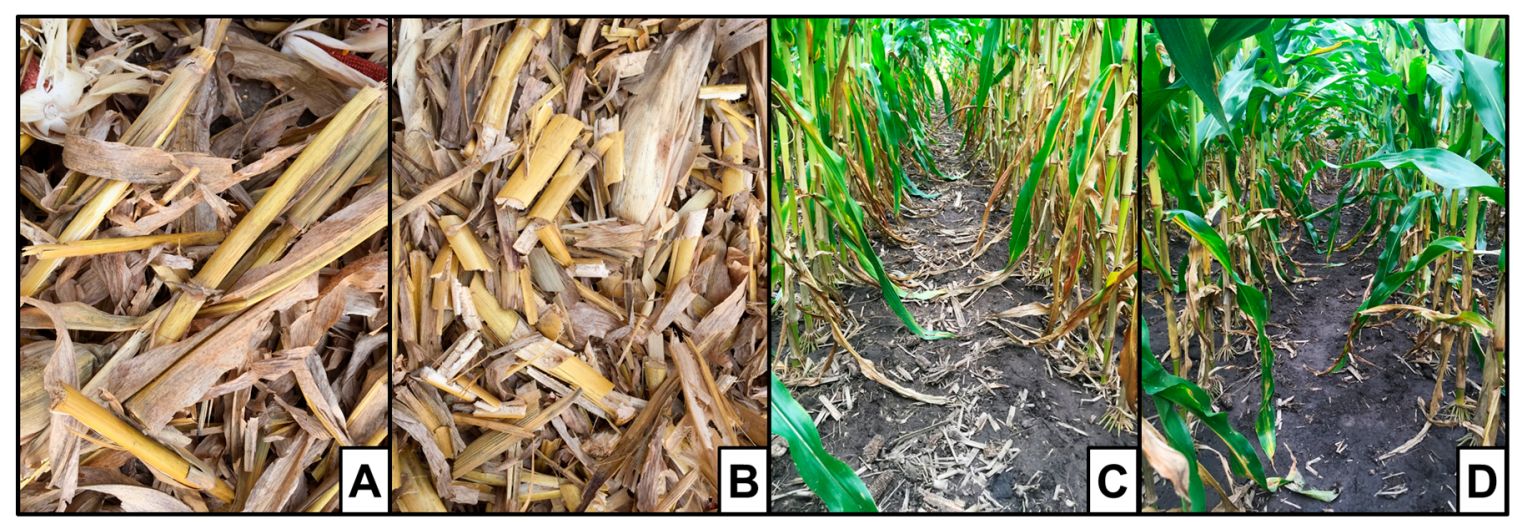

Figure 1. Mechanical residue management effects in continuous corn the previous fall $(\mathbf{A}, \mathbf{B})$ and at the R3 growth stage the following growing season $(\mathbf{C}, \mathbf{D})$ due to standard stalk rollers $(\mathbf{A}, \mathbf{C})$ and Calmer's BT chopper stalk rollers (B,D) at Champaign, IL, USA.

Intensive agronomic management significantly improved grain yield when averaged across crop rotations ( $2.08 \mathrm{Mg} \mathrm{ha}^{-1} ; p \leq 0.0001$ ) (Tables 7 and 8). Grain yield of continuous corn managed intensively was similar to that of corn grown in rotation with soybean and standard inputs. These data emphasize the importance of agronomic management in continuous corn and reflect results documented in other studies [11,42]. Across agronomic input levels and residue management, the CCYPs were 1.24 and $1.36 \mathrm{Mg} \mathrm{ha}^{-1}$ with hybrids 6110SS and 6594SS, respectively (Table 8). The CCYPs were reduced with mechanical residue management for both hybrids: 6110SS (CCYP of $1.47 \mathrm{Mg} \mathrm{ha}^{-1}$ with standard residue versus $1.01 \mathrm{Mg} \mathrm{ha}^{-1}$ with chopped residue) and 6594 SS (CCYP of $1.58 \mathrm{Mg} \mathrm{ha}^{-1}$ with standard residue versus $1.14 \mathrm{Mg} \mathrm{ha}^{-1}$ with chopped residue). These CCYP responses are in accord with the predicted responses noted by the hybrid seed company.

As grain yield level increased, stover biomass production increased (Tables 6 and 8), resulting in additional residue to be managed post-harvest, reinforcing the need to manage residue in not only continuous corn but also in high grain yield environments. Previous findings have also noted the positive correlation between increases in corn grain yield and the stover (surface residue) $[68,69]$, as well as that the quantity of corn residue increases with additional nitrogen, phosphorus, and potassium fertilization $[68,70,71]$, such as in the high input system used for the study presented here.

Harvest index was impacted by crop rotation, input level, and hybrid (Tables 6 and 7). Averaged across the trial, harvest index was 56\%, consistent with values for modern hybrids reported by Tollenaar [72]. Continuous corn plants had a lower harvest index than corn in rotation with soybean as a result of decreased grain yield but similar stover biomass. These results are in agreement with those of Attia et al. [56] and suggest that continuous corn is sink limited. Compared to high input, standard agronomic management led to a higher harvest index as a result of the significantly reduced stover biomass accumulation with the standard input level along with the lower grain yield. Hybrid 
6110SS had a higher harvest index compared to hybrid 6594SS, in agreement with other studies that documented differences in harvest index with genetic variation $[65,72]$.

\subsection{Yield Components and Grain Quality}

Both kernel number and kernel weight were significantly altered by crop rotation, input level, and hybrid, with mechanical residue management impacting kernel number (Table 7). Kernel number was $5 \%$ greater in plots rotated with soybean compared to following corn (4932 kernels $\mathrm{m}^{-2}$ versus $4685 \mathrm{kernels} \mathrm{m}^{-2}$, respectively) and $3 \%$ greater in plots that received chopped residue ( 4880 kernels $\mathrm{m}^{-2}$ )

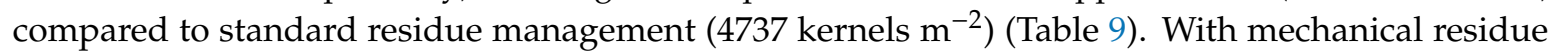
management, kernel weight remained constant, similar to findings of Sindelar et al., who reported increased kernel number and no change in kernel weight with residue management [51]. Individual kernel weight of corn grown continuously was $6 \%$ less than when grown in rotation with soybean (236 mg kernel ${ }^{-1}$ with continuous corn compared to $251 \mathrm{mg} \mathrm{kernel}^{-1}$ with corn-soybean). As a result, the higher yields of the corn-soybean rotation compared to the continuously grown corn yields were derived from a combination of both greater kernel number and heavier kernel weight (Table 9). These findings corroborate earlier reports of rotated versus continuous corn $[29,73]$ and further support the idea that continuous corn is sink limited.

Input level had the largest treatment effect on kernel number with a nearly $21 \%$ increase from intensive input compared to the standard input level (5264 kernels $\mathrm{m}^{-2}$ versus 4354 kernels $\mathrm{m}^{-2}$, respectively) (Table 9). However, compared to standard management, high input management reduced kernel weight by $4 \mathrm{mg} \mathrm{kernel}^{-1}$. When corn was rotated with soybean, kernel weight was unaffected by input level (251 mg kernel-1 $)$, whereas continuous corn grown with standard management resulted in kernels that weighed $240 \mathrm{mg}$, while kernels produced with the high input level weighed $232 \mathrm{mg}$. Overall, the improved grain yields with intensified agronomic management were a result of increased kernel number (Table 9).

Hybrid 6110SS had 7\% heavier and 4\% more kernels on average compared to hybrid 6594SS, resulting in the enhanced grain yield of 6110SS over 6594SS (Table 9). Kernel weight remained constant for hybrid 6594SS regardless of input level (235 $\left.\mathrm{mg} \mathrm{kernel}^{-1}\right)$, but hybrid 6110SS had greater kernel weight when grown with the standard compared to the intensive management (257 versus $248 \mathrm{mg} \mathrm{kernel}^{-1}$, respectively).

Chemical residue management had a significant effect on grain oil and starch concentrations (Table 7). Plots that received a fall application of AMS led to lower percent oil in the grain compared to untreated or Extract PBA-treated plots (Table 9). The Extract PBA treatment reduced grain starch concentration compared to the untreated control, while AMS-treated residue generated grain that had starch concentrations similar to both Extract PBA-treated and untreated plots. Grain protein levels were higher from plants grown in the corn-soybean rotation than with continuous corn $(6.69 \%$ versus $6.56 \%$, respectively) as well as plants grown in chopped residue $(6.69 \%)$ versus standard residue $(6.56 \%)$, suggesting that these treatments made additional nitrogen available for protein production. The increase in grain protein concentration with corn following soybean rather than corn is reflected in Maloney et al. as increased grain nitrogen levels [73]. Standard agronomic management resulted in a lower grain protein concentration $(6.57 \%)$ than the high input system (6.69\%). In continuously grown corn, the standard input level also resulted in a lower protein level in the grain compared to the high input, while rotated corn only trended in that direction. 
Table 9. Yield components and grain quality as influenced by crop rotation, mechanical and chemical residue management, input level, and corn hybrid when grown at Champaign, IL during 2017 and 2018. All values are reported at $0 \mathrm{~g} \mathrm{~kg}^{-1}$ moisture concentration.

\begin{tabular}{|c|c|c|c|c|c|c|c|}
\hline \multirow[b]{2}{*}{ Input Level } & \multirow[b]{2}{*}{ Hybrid } & \multirow[b]{2}{*}{ Chemical } & \multicolumn{2}{|c|}{ Yield Components } & \multicolumn{3}{|c|}{ Grain Quality } \\
\hline & & & Kernel number & Kernel Weight & Oil & Protein & Starch \\
\hline \multirow{2}{*}{\multicolumn{8}{|c|}{$\begin{array}{c}\mathrm{kernel} \mathrm{m}^{-2} \quad \mathrm{mg} \mathrm{kernel}{ }^{-1} \\
\text { Continuous Corn-Standard Residue Management }\end{array}$}} \\
\hline & & & & & & & \\
\hline \multirow[t]{6}{*}{ Standard } & \multirow[t]{3}{*}{ 6110SS } & Untreated & 4062 & 251.9 & 4.26 & 6.15 & 73.17 \\
\hline & & Extract PBA & 3947 & 248.3 & 4.09 & 5.98 & 73.57 \\
\hline & & $\mathrm{AMS}+$ & 4165 & 250.6 & 3.97 & 6.11 & 73.55 \\
\hline & \multirow[t]{3}{*}{ 6594SS } & Untreated & 4081 & 227.9 & 3.97 & 6.55 & 73.65 \\
\hline & & Extract PBA & 4084 & 233.1 & 4.00 & 6.64 & 73.46 \\
\hline & & AMS & 4250 & 231.1 & 3.91 & 6.70 & 73.49 \\
\hline \multirow[t]{6}{*}{ Intensive } & \multirow[t]{3}{*}{ 6110SS } & Untreated & 4982 & 237.9 & 4.15 & 6.11 & 73.77 \\
\hline & & Extract PBA & 4973 & 241.2 & 4.04 & 6.10 & 73.50 \\
\hline & & AMS & 5167 & 232.3 & 3.98 & 6.18 & 73.80 \\
\hline & \multirow[t]{3}{*}{$6594 S S$} & Untreated & 5040 & 218.9 & 4.10 & 6.89 & 73.45 \\
\hline & & Extract PBA & 5064 & 232.0 & 4.10 & 6.96 & 73.07 \\
\hline & & AMS & 5190 & 223.5 & 3.94 & 7.07 & 73.46 \\
\hline \multicolumn{8}{|c|}{ Continuous Corn-Chopped Residue Management } \\
\hline \multirow[t]{6}{*}{ Standard } & \multirow[t]{3}{*}{ 6110SS } & Untreated & 4200 & 255.4 & 4.17 & 6.17 & 73.47 \\
\hline & & Extract PBA & 4192 & 246.4 & 4.29 & 6.28 & 73.16 \\
\hline & & AMS & 4211 & 250.8 & 4.17 & 6.29 & 73.45 \\
\hline & 6594SS & Untreated & 4440 & 227.2 & 3.96 & 6.83 & 73.42 \\
\hline & & Extract PBA & 4461 & 224.4 & 4.38 & 7.01 & 72.85 \\
\hline & & AMS & 4442 & 229.0 & 4.15 & 7.03 & 73.22 \\
\hline Intensive & 6110SS & Untreated & 5191 & 243.6 & 4.18 & 6.31 & 73.71 \\
\hline & & Extract PBA & 5114 & 241.9 & 4.04 & 6.40 & 73.76 \\
\hline & & AMS & 5129 & 238.1 & 4.14 & 6.60 & 73.56 \\
\hline & 6594SS & Untreated & 5426 & 225.2 & 4.18 & 7.02 & 73.49 \\
\hline & & Extract PBA & 5268 & 229.6 & 4.16 & 6.99 & 73.30 \\
\hline & & AMS & 5372 & 222.6 & 3.96 & 7.20 & 73.55 \\
\hline & & Corn-Soybean & otation-Standa & Residue Manag & & & \\
\hline Standard & 6110SS & Untreated & 4345 & 262.8 & 4.22 & 6.24 & 73.26 \\
\hline & & Extract PBA & 4365 & 266.2 & 4.36 & 6.49 & 73.03 \\
\hline & & AMS & 4238 & 267.3 & 4.17 & 6.35 & 73.24 \\
\hline & 6594SS & Untreated & 4401 & 239.9 & 4.01 & 6.75 & 73.70 \\
\hline & & Extract PBA & 4630 & 243.6 & 4.19 & 7.04 & 73.06 \\
\hline & & AMS & 4631 & 237.9 & 3.99 & 6.85 & 73.50 \\
\hline Intensive & 6110SS & Untreated & 5364 & 255.3 & 4.14 & 6.40 & 73.61 \\
\hline & & Extract PBA & 5259 & 259.2 & 4.19 & 6.39 & 73.36 \\
\hline & & AMS & 5235 & 257.4 & 4.15 & 6.46 & 73.26 \\
\hline & 6594SS & Untreated & 5273 & 244.9 & 4.08 & 7.00 & 73.16 \\
\hline & & Extract PBA & 5630 & 248.0 & 4.14 & 7.04 & 73.24 \\
\hline & & AMS & 5316 & 244.6 & 4.11 & 7.05 & 73.18 \\
\hline & & Corn-Soybean & otation-Choppe & Residue Manag & & & \\
\hline Standard & 6110SS & Untreated & 4507 & 262.4 & 4.22 & 6.39 & 73.54 \\
\hline & & Extract PBA & 4443 & 259.6 & 4.36 & 6.49 & 73.06 \\
\hline & & AMS & 4406 & 262.0 & 4.22 & 6.46 & 73.31 \\
\hline & 6594SS & Untreated & 4626 & 240.4 & 4.09 & 6.99 & 73.45 \\
\hline & & Extract PBA & 4767 & 238.2 & 4.08 & 6.95 & 73.46 \\
\hline & & AMS & 4592 & 235.0 & 3.99 & 6.96 & 73.29 \\
\hline Intensive & 6110SS & Untreated & 5266 & 251.2 & 4.16 & 6.53 & 73.61 \\
\hline & & Extract PBA & 5282 & 255.2 & 4.23 & 6.36 & 73.66 \\
\hline & & AMS & 5177 & 260.1 & 4.01 & 6.34 & 73.73 \\
\hline & 6594SS & Untreated & 5299 & 244.0 & 4.22 & 7.05 & 73.18 \\
\hline & & Extract PBA & 5588 & 247.2 & 4.25 & 7.05 & 73.17 \\
\hline & & AMS & 5731 & 240.4 & 4.16 & 7.00 & 73.15 \\
\hline & $\mathrm{n} \operatorname{LSD}(p$ & & 91 & 5.6 & NS & 0.11 & 0.10 \\
\hline Mechanical Re & Manage & $\operatorname{LSD}(p \leq 0.10)$ & 82 & NS & NS & 0.10 & NS \\
\hline Chemical Res & Managen & $\operatorname{LSD}(p \leq 0.10)$ & NS $\ddagger$ & NS & 0.05 & NS & 0.12 \\
\hline Inp & vel LSD & $10)$ & $59^{\top}$ & 2.3 & NS & 0.06 & NS \\
\hline & $d \operatorname{LSD}(p$ & & 58 & 2.3 & 0.04 & 0.06 & 0.10 \\
\hline
\end{tabular}

† AMS, ammonium sulfate. $\ddagger$ NS, nonsignificant.

Hybrid influenced all grain quality parameters (oil, protein, and starch levels) (Table 9). With the higher yield of 6110SS, oil concentrations were higher and protein concentrations were lower in the grain (4.16\% oil and $6.32 \%$ protein) compared to those of hybrid $6594 \mathrm{SS}$ (4.09\% oil and $6.94 \%$ protein). Grain starch concentration was higher with hybrid 6110SS (73.46\%) compared to hybrid $6594 \mathrm{SS}$ 
(73.33\%). Starch levels at both input levels were similar for 6595SS, while 6110SS had elevated starch levels when grown with high input management. Continuous corn plots exhibited a higher level of starch in the grain compared to rotated corn plots (73.45\% versus $73.34 \%$, respectively). Hybrid $6594 \mathrm{SS}$ had a constant oil concentration in the grain regardless of input level, unlike 6110SS, which produced greater oil levels with standard agronomic management compared to high input management.

\subsection{Correlations between Crop Growth and Final Grain Yield}

Early season plant growth assessments at the V6 growth stage, whether above- or below-ground, correlated to final grain yield (Table 10). According to Evans' correlation strength classifications, shoot biomass at V6 and grain yield had a positive weak correlation, while V6 root biomass and grain yield had a positive moderate correlation [74]. In contrast, shoot to root ratios had a negative weak correlation to grain yield. Intensive management reduced SPAD readings due to the increased planting population; conversely, crop rotation increased SPAD readings. However, both treatments significantly increased grain yield, resulting in a weak but significant positive correlation to grain yield. Kernel number had a very strong positive correlation to final grain yield, as demonstrated in other studies $[29,43,57,75]$, in addition to a weak positive correlation between kernel weight and final grain yield. As R6 stover biomass increased, grain yield increased, resulting in additional residue accumulation on the soil surface $(r=0.80 ; p \leq 0.0001)$ (Table 10). These correlations show the influence of crop growth and development throughout the season to maintain grain yield potential.

Table 10. Pearson correlation coefficients and associated significance level for final grain yield between selected corn growth parameters for the continuous corn trial conducted at Champaign, IL during 2017 and 2018.

\begin{tabular}{cc}
\hline Corn Parameter & Correlation $r$ \\
\hline V6 Shoot Biomass & $0.35^{* * *}$ \\
V6 Root Biomass & $0.53^{* * *}$ \\
V6 Shoot:Root & $-0.34^{* * *}$ \\
R2 SPAD & $0.19^{* * *}$ \\
R6 Stover & $0.80^{* * *}$ \\
Kernel Number & $0.92^{* * *}$ \\
Kernel Weight & $0.37^{* * *}$ \\
\hline${ }^{* * *}$ Significant at the 0.001 probability level.
\end{tabular}

\section{Conclusions}

In continuous corn cropping systems, crop stress induced from larger corn residue pieces was reduced by mechanically decreasing fragment size, demonstrated through enhanced residue decomposition, increased seedling emergence, and greater yield. Early season growth differences were primarily driven by altered agronomic input level and hybrid, while crop rotation differences did not appear until the R2 reproductive stage, when stress induced by continuous corn cropping was detected.

Without enhanced fertility (i.e., standard management), continuous corn plots yielded significantly less than corn following soybean. In both crop rotations, there was an increased kernel number from the intensive input system; however, in continuous corn, this change was offset by a lower kernel weight, while for corn in rotation with soybean, the kernel weight was maintained. Rotation, down-sized residue, and high input management all enhanced percent grain protein. Using an input system consisting of sized residue, greater population, and additional fertilizer and fungicide allowed the corn grown continuously to achieve yields similar to corn rotated with soybean grown in a standard management system. 
Stover biomass at the end of the season had a strong positive correlation with final grain yield, indicating that higher grain yields resulted in increased residue remaining in the field at harvest $(r=0.80 ; p \leq 0.001)$. As a result, residue management will continue to be of importance as genetic and cultural practices strive to increase grain yield. Removal of residue can deplete the soil and deprive the future crop of the potential nutrition residing within the residue, encouraging the investigation of methods to manage residue in place. While chemical treatments applied in the fall to stover residue enhanced subsequent R2 leaf greenness, they did not translate into greater grain yield, whereas mechanical sizing of corn residue had a larger effect at the $\mathrm{R} 2$ growth stage and did alter final grain yield. Therefore, continuous corn cropping and increased residue situations can be more sustainably managed through mechanical sizing of residue, selecting superior genetics, and implementing an enhanced input management system, resulting in better yields.

Author Contributions: Formal analysis, A.M.V.; Funding acquisition, F.E.B.; Investigation, A.M.V.; Methodology, A.M.V.; Project administration, F.E.B.; Resources, F.E.B.; Writing—original draft, A.M.V.; Writing一review \& editing, F.E.B.

Funding: This research was made possible with partial funding from the National Institute of Food and Agriculture project NC1200 "Regulation of Photosynthetic Processes" and the Illinois AES project 802-908. We also greatly appreciate the support from Calmer Corn Heads, Agricen, and the Mosaic Company.

Acknowledgments: We would like to thank the Crop Physiology Lab personnel for field and data collection, and especially Juliann Seebauer for manuscript preparation.

Conflicts of Interest: The authors declare no conflict of interest.

\section{References}

1. Shapiro, C.A.; Wortmann, C.S. Corn response to nitrogen rate, row spacing, and plant density in eastern. Nebraska. Agron. J. 2006, 98, 529-535. [CrossRef]

2. Vogel, A.M.; Below, F.E. Hybrid selection and agronomic management to lessen the continuous corn yield penalty. Agronomy 2018, 8, 228. [CrossRef]

3. Bockus, W.W.; Shroyer, J.P. The impact of reduced tillage on soilborne plant pathogens. Annu. Rev. Phytopathol. 1998, 36, 485-500. [CrossRef] [PubMed]

4. Meese, B.G.; Carter, P.R.; Oplinger, E.S.; Pendleton, J.W. Corn/soybean rotation effect as influenced by tillage, nitrogen, and hybrid/cultivar. J. Prod. Agric. 1991, 4, 74-80. [CrossRef]

5. Gentry, L.F.; Ruffo, M.L.; Below, F.E. Identifying factors controlling the continuous corn yield penalty. Agron. J. 2013, 105, 295-303. [CrossRef]

6. Graham, R.L.; Nelson, R.; Sheehan, J.; Perlack, R.D.; Wright, L.L. Current and potential U.S. corn stover supplies. Agron. J. 2007, 99, 1-11. [CrossRef]

7. Van Doren, D.M.; Triplett, G.B.; Henry, J.E. Influence of long term tillage, crop rotation, and soil type combinations on corn yield. Soil Sci. Soc. Am. J. 1976, 40, 100-105. [CrossRef]

8. Peterson, T.A.; Varvel, G.E. Crop yield as affected by rotation and nitrogen rate. III. Corn. Agron. J. 1989, 81, 735-738. [CrossRef]

9. Porter, P.M.; Lauer, J.G.; Lueschen, W.E.; Ford, J.H.; Hoverstad, T.R.; Oplinger, E.S.; Crookston, R.K. Environment affects the corn and soybean rotation effects. Agron. J. 1997, 89, 442-448. [CrossRef]

10. Howard, D.D.; Chambers, A.Y.; Lessman, G.M. Rotation and fertilization effects on corn and soybean yields and soybean cyst nematode populations in a no-tillage system. Agron. J. 1998, 90, 518-522. [CrossRef]

11. Katsvairo, T.W.; Cox, W.J. Tillage x rotation x management interactions in corn. Agron. J. 2000, 92, 493-500. [CrossRef]

12. Pedersen, P.; Lauer, J.G. Corn and soybean response to rotation sequence, row spacing, and tillage system. Agron. J. 2003, 95, 965-971. [CrossRef]

13. Pikul, J.L.; Hammack, L.; Riedell, W.E. Corn yield, N use and corn rootworm infestation of rotations in the northern Corn Belt. Agron. J. 2005, 97, 854-863. [CrossRef]

14. Stanger, T.F.; Lauer, J.G.; Chavas, J.-P. Long-term cropping systems: The profitability and risk of cropping systems featuring different rotations and nitrogen rates. Agron. J. 2008, 100, 105-113. [CrossRef] 
15. Swan, J.B.; Schneider, E.C.; Moncrief, J.F.; Paulson, W.H.; Peterson, A.E. Estimating corn growth, yield, and grain moisture from air growing degree days and residue cover. Agron. J. 1987, 79, 53-60. [CrossRef]

16. Liu, W.; Tollenaar, M.; Stewart, G.; Deen, W. Response of corn grain yield to spatial and temporal variability in emergence. Crop Sci. 2004, 44, 847-854. [CrossRef]

17. Mehdi, B.B.; Madramootoo, C.A.; Mehuys, G.R. Yield and nitrogen content of corn under different tillage practices. Agron. J. 1999, 91, 631-636. [CrossRef]

18. Nafziger, E.D.; Carter, P.R.; Graham, E.E. Response of corn to uneven emergence. Crop Sci. 1991, 31, 811-815. [CrossRef]

19. Blanco-Canqui, H.; Lal, R.; Post, W.M.; Owens, L.B. Changes in long-term no-till corn growth and yield under different rates of stover mulch. Agron. J. 2006, 98, 1128-1136. [CrossRef]

20. Blanco-Canqui, H.; Lal, R. Corn stover removal for expanded uses reduces soil fertility and structural stability. Soil Sci. Soc. Am. J. 2009, 73, 418-426. [CrossRef]

21. Karlen, D.L.; Hunt, P.G.; Campbell, R.B. Crop residue removal effects on corn yield and fertility of a Norfolk sandy loam. Soil Sci. Soc. Am. J. 1984, 48, 868-872. [CrossRef]

22. Wilhelm, W.W.; Johnson, J.M.F.; Hatfield, J.L.; Voorhees, W.B.; Linden, D.R. Crop and soil productivity response to corn residue removal: A literature review. Agron. J. 2004, 96, 1-17. [CrossRef]

23. Janzen, H.H.; Kucey, R.M.N. C, N, and S mineralization of crop residues as influenced by crop species and nutrient regime. Plant Soil 1988, 106, 35-41. [CrossRef]

24. Kumar, K.; Goh, K.M. Crop residues and management practices: Effects on soil quality, soil nitrogen dynamics, crop yield, and nitrogen recovery. Adv. Agron. 1999, 68, 197-319. [CrossRef]

25. Havlin, J.L.; Tisdale, S.L.; Nelson, W.L.; Beaton, J.D. Soil Fertility and Fertilizers: An Introduction to Nutrient Management, 7th ed.; Pearson Education: Upper Saddle River, NJ, USA, 2007; pp. 119-122.

26. Aulakh, M.S.; Walters, D.T.; Doran, J.W.; Francis, D.D.; Mosier, A.R. Crop residue type and placement effects on denitrification and mineralization. Soil Sci. Soc. Am. J. 1991, 55, 1020-1025. [CrossRef]

27. Johnson, J.M.F.; Barbour, N.W.; Lachnicht-Weyers, S. Chemical composition of crop biomass impacts its decomposition. Soil Sci. Soc. Am. J. 2007, 71, 155-162. [CrossRef]

28. Gentry, L.E.; Below, F.E.; David, M.B.; Bergerou, J.A. Source of the soybean N credit in maize production. Plant Soil 2001, 236, 175-184. [CrossRef]

29. Bergerou, J.A.; Gentry, L.E.; David, M.B.; Below, F.E. Role of $\mathrm{N}_{2}$ fixation in the soybean $\mathrm{N}$ credit in maize production. Plant Soil 2004, 262, 383-394. [CrossRef]

30. Ambus, P.; Jensen, E.S. Nitrogen mineralization and denitrification as influenced by crop residue particle size. Plant Soil 1997, 197, 261-270. [CrossRef]

31. Broder, M.W.; Wagner, G.H. Microbial colonization and decomposition of corn, wheat, and soybean residue. Soil Sci. Soc. Am. J. 1988, 52, 112-117. [CrossRef]

32. Calvo, P.; Nelson, L.; Kloepper, J.W. Agriculture uses of plant biostimulants. Plant Soil. 2014, $383,3-41$. [CrossRef]

33. Adesemoye, A.O.; Yuen, G.; Watts, D.B. Microbial inoculants for optimized plant nutrient use in integrated pest and input management systems. In Probiotics and Plant Health; Kumar, V., Kumar, M., Sharma, S., Prasad, R., Eds.; Springer: Singapore, 2017; pp. 21-40.

34. Rodriguez, H.; Fraga, R. Phosphate solubilizing bacteria and their role in plant growth promotion. Biotechnol. Adv. 1999, 17, 319-339. [CrossRef]

35. Rodriguez, H.; Fraga, R.; Gonzalez, T.; Bashan, Y. Genetics of phosphate solubilization and its potential applications for improving plant growth-promoting bacteria. Plant Soil 2006, 287, 15-21. [CrossRef]

36. Friedrich, S.; Platonova, N.P.; Karavaiko, G.I.; Stichel, E.; Glombitza, F. Chemical and microbiological solubilization of silicates. Acta Biotechnol. 1991, 11, 187-196. [CrossRef]

37. Han, H.S.; Lee, K.D. Phosphate and potassium solubilizing bacteria effect on mineral uptake, soil availability and growth of eggplant. Res. J. Agric. Biol. Sci. 2005, 1, 176-180.

38. Sheng, X.F.; He, L.Y. Solubilization of potassium-bearing minerals by a wild-type strain of Bacillus edaphicus and its mutants and increased potassium uptake by wheat. Can. J. Microbiol. 2006, 52, 66-72. [CrossRef]

39. Calvo, P.; Watts, D.B.; Ames, R.N.; Kloepper, J.W.; Torbert, H.A. Microbial-based inoculants impact nitrous oxide emissions from an incubated soil medium containing urea fertilizers. J. Environ. Qual. 2013, 42, 704-712. [CrossRef] 
40. Knorr, M.; Frey, S.D.; Curtis, P.S. Nitrogen additions and litter decomposition: A meta-analysis. Ecology 2005, 86, 3252-3257. [CrossRef]

41. Al-Kaisi, M.M.; Guzman, J.G. Effects of tillage and nitrogen rate on decomposition of transgenic Bt and near-isogenic non-Bt maize residue. Soil Tillage Res. 2013, 129, 32-39. [CrossRef]

42. Riedell, W.E.; Schumacher, T.E.; Clay, S.A.; Ellsbury, M.M.; Pravecek, M.; Evenson, P.D. Corn and soil fertility responses to crop rotation with low, medium, or high inputs. Crop Sci. 1998, 38, 427-433. [CrossRef]

43. Ruffo, M.L.; Gentry, L.F.; Henninger, A.S.; Seebauer, J.R.; Below, F.E. Evaluating management factor contributions to reduce corn yield gaps. Agron. J. 2015, 107, 495-505. [CrossRef]

44. Jeschke, M.; Doerge, T. Management of foliar diseases in corn with fungicides. Crop Insights 2010, 18, 1-4.

45. Goering, H.K.; Van Soest, P.J. Forage Fibre Analyses: Apparatus Reagents, Procedures and Some Applications; USDA Handb. No. 379; U.S. Govt. Printing Offices: Washington, DC, USA, 1970.

46. Moore, J.C.; Walter, D.E.; Hunt, H.W. Arthropod regulation of micro- and mesobiota in below-ground detrital food webs. Annu. Rev. Entomol. 1988, 33, 419-439. [CrossRef]

47. Angers, D.A.; Recous, S. Decomposition of wheat straw and rye residues as affected by particle size. Plant Soil 1997, 189, 197-203. [CrossRef]

48. Stetson, S.J.; Lehman, R.M.; Osborne, S.L. Corn residue particle size affects soil surface properties. Agric. Environ. Lett. 2018, 3, 180004. [CrossRef]

49. Bender, R.R.; Haegele, J.W.; Ruffo, M.L.; Below, F.E. Nutrient uptake, partitioning, and remobilization in modern, transgenic insect-protected maize hybrids. Agron. J. 2013, 105, 161-170. [CrossRef]

50. Ouyang, D.; MacKenzie, A.F.; Fan, M. Phytotoxicity of banded urea amended with triple superphosphate and potassium chloride. Agron. J. 1998, 90, 734-739. [CrossRef]

51. Sindelar, A.J.; Coulter, J.A.; Lamb, J.A.; Vetsch, J.A. Agronomic responses of continuous corn to stover, tillage, and nitrogen management. Agron. J. 2013, 105, 1498-1506. [CrossRef]

52. Riedell, W.E.; Pikul, J.L.; Jaradat, A.A.; Schumacher, T.E. Crop rotation and nitrogen input effects on soil fertility, maize mineral nutrition, yield, and seed composition. Agron. J. 2009, 101, 870-879. [CrossRef]

53. Ciampitti, I.A.; Vyn, T.J. Physiological perspectives of changes over time in maize yield dependency on nitrogen uptake and associated nitrogen efficiencies: A review. Field Crops Res. 2012, 133, 48-67. [CrossRef]

54. Crookston, R.K.; Kurle, J.E.; Copeland, P.J.; Ford, J.H.; Lueschen, W.E. Rotational cropping sequence affects yield of corn and soybean. Agron. J. 1991, 83, 108-113. [CrossRef]

55. Shanahan, J.F.; Schepers, J.S.; Francis, D.D.; Varvel, G.E.; Wilhelm, W.W.; Tringe, J.M.; Schlemmer, M.R.; Major, D.J. Use of remote-sensing imagery to estimate corn grain yield. Agron. J. 2001, 93, 583-589. [CrossRef]

56. Attia, A.; Shapiro, C.; Kranz, W.; Mamo, M.; Mainz, M. Improved yield and nitrogen use efficiency of corn following soybean in irrigated sandy loams. Soil Sci. Soc. Am. J. 2015, 79, 1693-1703. [CrossRef]

57. Ennin, S.A.; Clegg, M.D. Effect of soybean plant population in a soybean and maize rotation. Agron. J. 2001, 93, 396-403. [CrossRef]

58. Johnson, J.W.; Welch, L.F.; Kurtz, L.T. Environmental implications of N fixation by soybeans. J. Environ. Qual. 1975, 4, 303-306. [CrossRef]

59. Bender, R.R.; Haegele, J.W.; Below, F.E. Nutrient uptake, partitioning, and remobilization in modern soybean varieties. Agron. J. 2015, 107, 563-573. [CrossRef]

60. Power, J.F.; Doran, J.W.; Wilhelm, W.W. Uptake of nitrogen from soil fertilizer and crop residues by no-till corn and soybean. Soil Sci. Soc. Am. J. 1986, 50, 137-142. [CrossRef]

61. Blackmer, T.M.; Schepers, J.S.; Varvel, G.E. Light reflectance compared with other nitrogen stress measurements in corn leaves. Agron. J. 1994, 86, 934-938. [CrossRef]

62. Hatfield, J.L.; Gitelson, A.A.; Schepers, J.S.; Walthall, C.L. Application of spectral remote sensing for agronomic decisions. Agron. J. 2008, 100, S117-S131. [CrossRef]

63. Hashemi-Dezfouli, A.; Herbert, S.J. Intensifying plant density response of corn with artificial shade. Agron. J. 1992, 84, 547-551. [CrossRef]

64. Tajul, M.I.; Alam, M.M.; Hossain, S.M.M.; Naher, K.; Rafii, M.Y.; Latif, M.A. Influence of plant population and nitrogen-fertilizer at various levels on growth and growth efficiency of maize. Sci. World J. 2013, 2013, 193018. [CrossRef]

65. Subedi, K.D.; Ma, B.L. Nitrogen uptake and partitioning in stay-green and leafy maize hybrids. Crop Sci. 2005, 45, 740-747. [CrossRef] 
66. Hokmalipour, S.; Darbandi, M.H. Effects of nitrogen fertilizer on chlorophyll content and other leaf indicate in three cultivars of maize (Zea mays L.). World Appl. Sci. J. 2011, 15, 1780-1785.

67. Sindelar, A.J.; Schmer, M.R.; Jin, V.L.; Wienhold, B.J.; Varvel, G.E. Long-term corn and soybean response to crop rotation and tillage. Agron. J. 2015, 107, 2241-2252. [CrossRef]

68. Huggins, D.R.; Fuchs, D.J. Long-term N management effects on corn yield and soil C of an aquic Haplustoll in Minnesota. In Soil Organic Matter in Temperate Ecosystems: Long-Term Experiments in North America; Paul, E.A., Paustian, K.H., Cole, C.V., Eds.; CRC Press: Boca Raton, FL, USA, 1997; pp. 121-128.

69. Lorenz, A.J.; Gustafson, T.J.; Coors, J.G.; De Leon, N. Breeding maize for a bioeconomy: A literature survey examining harvest index and stover yield and their relationship to grain yield. Crop Sci. 2010, 50, 1-12. [CrossRef]

70. Gregorich, E.G.; Ellert, B.H.; Drury, C.F.; Liang, B.C. Fertilization effects on soil organic matter turnover and corn residue C storage. Soil Sci. Soc. Am. J. 1996, 60, 472-476. [CrossRef]

71. Wilts, A.R.; Reicosky, D.C.; Allmaras, R.R.; Clapp, C.E. Long-term corn residue effects: Harvest alternatives, soil carbon turnover, and root-derived carbon. Soil Sci. Soc. Am. J. 2004, 68, 1342-1351. [CrossRef]

72. Tollenaar, M. Genetic improvement in grain yield of commercial maize hybrids grown in Ontario from 1959 to 1988. Crop Sci. 1989, 29, 1365-1371. [CrossRef]

73. Maloney, T.S.; Silveira, K.G.; Oplinger, E.S. Rotational vs. nitrogen-fixing influence of soybean on corn grain and silage yield and nitrogen use. J. Prod. Agric. 1999, 12, 175-187. [CrossRef]

74. Evans, J.D. Straightforward Statistics for Behavioral Sciences; Brooks/Cole Publishing: Pacific Grove, CA, USA, 1996.

75. Haegele, J.W.; Becker, R.J.; Henninger, A.S.; Below, F.E. Row arrangement, phosphorus fertility, and hybrid contributions to managing increased plant density of maize. Agron. J. 2014, 106, 1838-1846. [CrossRef]

(C) 2019 by the authors. Licensee MDPI, Basel, Switzerland. This article is an open access article distributed under the terms and conditions of the Creative Commons Attribution (CC BY) license (http://creativecommons.org/licenses/by/4.0/). 